archives-ouvertes

\title{
Numerical simulation of the wind influence on bottom shear stress and salinity fields in areas of Zostera noltei replanting in a Mediterranean coastal lagoon
}

E. Alekseenko, Bernard Roux

\section{- To cite this version:}

E. Alekseenko, Bernard Roux. Numerical simulation of the wind influence on bottom shear stress and salinity fields in areas of Zostera noltei replanting in a Mediterranean coastal lagoon. Progress in Oceanography, Elsevier, 2018, 163, pp.147-160. 10.1016/j.pocean.2017.05.001 . hal-02111578

\section{HAL Id: hal-02111578 \\ https://hal-amu.archives-ouvertes.fr/hal-02111578}

Submitted on 26 Apr 2019

HAL is a multi-disciplinary open access archive for the deposit and dissemination of scientific research documents, whether they are published or not. The documents may come from teaching and research institutions in France or abroad, or from public or private research centers.
L'archive ouverte pluridisciplinaire HAL, est destinée au dépôt et à la diffusion de documents scientifiques de niveau recherche, publiés ou non, émanant des établissements d'enseignement et de recherche français ou étrangers, des laboratoires publics ou privés. 


\title{
Numerical simulation of the wind influence on bottom shear stress and salinity fields in areas of Zostera noltei replanting in a Mediterranean coastal lagoon
}

\author{
E. Alekseenko ${ }^{\text {a,b,c,*, }, \text { B. Roux }}{ }^{\mathrm{d}}$ \\ ${ }^{a}$ P.P. Shirshov Institute of Oceanology, Russian Academy of Sciences, Nakhimovsky prospect 36, Moscow, Russia \\ ${ }^{\mathrm{b}}$ People's Friendship University of Russia, Moscow, Russia \\ ${ }^{\mathrm{c}}$ Aix-Marseille Université, Université de Toulon, CNRS/INSU, IRD, MIO, UM 110, 13288 Marseille Cedex 09, France \\ ${ }^{\mathrm{d}}$ Aix-Marseille Université, CNRS, Centrale Marseille, M2P2 UMR 7340, 13451 Marseille, France
}

\section{A R T I C L E I N F O}

Article history:

Available online 13 May 2017

Keywords:

Etang de Berre

Hydrodynamics

Salinity

Numerical modelling

Mediterranean lagoon

\section{A B S T R A C T}

The paper concerns the numerical simulation of the wind influence on bottom shear stress and salinity fields in a semi-enclosed coastal lagoon (Etang de Berre) which is connected to the Mediterranean through a long and narrow channel (called Caronte). Two different scenarios are considered. The first scenario (scen.\#1), starting with a homogeneous salinity of $S=20$ PSU and without wind forcing, studies a stratification process under the influence of a periodic seawater inflow and a strong freshwater inflow from a hydropower plant $\left(250 \mathrm{~m}^{3} / \mathrm{s}\right.$ ). Then, in the second scenario (scen.\#2), we study how a strong wind of $80 \mathrm{~km} / \mathrm{h}$ can destroy the haline stratification obtained at the end of scen.\#1. The MARS3D numerical model is used to analyze the 3D current and salinity distribution induced by these three meteorological, oceanic and anthropogenic forcings in this lagoon and in the Caronte channel.

The main goal is to determine the bottom shear stress (BSS) in the nearshore areas of Zostera noltei replanting, and to compare it with the threshold for erosion of the bottom sediments for different bottom roughness parameters.

The most interesting results concern the four nearshore replanting areas; two are situated on the eastern side of EB and two on the western side. The results of scen.\#2 show that all these areas are subject to a downwind coastal jet. The destratification process is very beneficial; salinity always remains greater than 12 PSU for a N-NW wind of $80 \mathrm{~km} / \mathrm{h}$ and a hydropower runoff of $250 \mathrm{~m}^{3} / \mathrm{s}$. Concerning BSS, it presents a maximum near the shoreline and decreases along transects perpendicular to the shoreline. There exists a zone, parallel to the shoreline, where BSS presents a minimum (where BSS $=0$ ). When comparing the BSS value at the four control points with the critical value, BSS $_{c r}$, at which the sediment mobility would occur, we see that for the smaller bottom roughness values (ranging from $z_{0}=3.5 \times 10^{-4} \mathrm{~mm}$, to $3.5 \times 10^{-2} \mathrm{~mm}$ ) BSS largely surpasses this critical value. For a N-NW wind speed of $40 \mathrm{~km} / \mathrm{h}$ (which is blowing for around 100 days per year), BSS still largely surpasses BSS $_{c r}$ - at least for the silt sediments (ranging from $z_{0}=3.5 \times 10^{-4} \mathrm{~mm}$, to $3.5 \times 10^{-3} \mathrm{~mm}$ ). This confirms the possibility that the coastal jet could be a stressor for SAV replanting.

\section{Introduction}

This work is connected to the restoration, including a replanting program, of Zostera noltei (Z.n.) - an intertidal dwarf-eelgrass in the Etang de Berre (EB) which is one of the largest urbanized Mediterranean lagoon near Marseille (South of France). The massive loss of

\footnotetext{
* Corresponding author at: P.P. Shirshov Institute of Oceanology, Russian Academy of Sciences, Nakhimovsky prospect 36, Moscow, Russia.

E-mail address: lena.alekseenko@gmail.com (E. Alekseenko).
}

submerged aquatic vegetation (SAV), all along the coastal ocean, is a common worldwide ecological problem. For the Mediterranean Sea, the drastic loss of Posidonia oceanica meadows is reported by Telesca et al. (2015). It was previously mentioned in a report (HCMR, 2009) which also indicated a drastic loss of Zostera sp. The conservation and restoration of seagrass meadows provide a strategy to mitigate climate change while conserving these important ecosystems (Duarte et al., 2013).

It is mentioned by Warner (2012) that Z.n. meadows in EB were severely destroyed in the last fifty years due to anthropogenic 
water pollution and huge freshwater outflow from a hydroelectric power plant built in 1966 .

The release of freshwater and silt in EB for a long time led to a complete destabilization of the ecological functioning of the entire lagoon, causing intense eutrophication and disappearance of various marine biological indicators. Since the 1990 s, various managing strategies of the hydroelectric power plant have been imposed to protect the lagoon against telluric pollution, to restore the ecological status of the lagoon and to reduce its impact on the lagoon habitats. For all these aspects, EB is representative of urbanized Mediterranean lagoons. The present work deals with the impact of human activities on coastal ecosystems that are intensively studied in the framework of the MERMEX program (The Mermex group, 2011).

Fortunately, during the last decade, the hydropower outflow was reduced and regulated, and resilience of Z.n. meadows were observed in situ during the last four years by divers of a non-profit association (called L'Etang Nouveau) in several areas very close to the shoreline; these observations are very promising as the divers confirm that these meadows are now increasing year after year (Bazile, 2015; Bazile, 2016).

Z.n. - to be restored in EB - are marine flowering plants having a root and true rhizome system. They generally colonize soft substrates (mud/sand) which can be easily eroded by the bottom shear stress.

The critical level of burial or erosion tolerated by this species is extremely low (between 4 and $8 \mathrm{~cm}$ ) due to the small size of the species and the lack of vertical rhizomes (Cabaco and Santos, 2007). These limits concerning resilience of Z.n. to burial or erosion disturbances are experimentally confirmed by a more recent work by Han et al. (2012).

The difficulty of SAV seedling in soft substrate is well analyzed in a recent paper by Alagna et al. (2015) which studies suitable substrates for seedling anchorage vs hydrodynamic conditions in the case of Posidonia oceanica. In another interesting paper devoted to the Zostera Marina restoration Pickerell (2007) describes how the sites were selected. Pickerell (2007) wrote: "over the last dec-ade we have had a major paradigm shift with regard to site selec-tion. Whereas we used to focus on creeks and harbors with fine sediments we now work almost exclusively in sands and gravels in higher energy sites.

It is well known that the inflow of freshwater and seawater into coastal lagoons is an important factor influencing the structure and function of lagoon ecosystems worldwide (Smith, 1994; Lirman et al., 2008). Natural and man-made channels, as well as the bot-tom topography of lagoons, play an important role in guiding the tidal circulation and thus controlling advective transport (Dilorenzo, 1988, Smith, 1994). Water circulation along the Mediterranean shores is influenced by tidal flow (with semi-diurnal oscillations of small amplitude) combined with other forc-ing mechanisms (Millot, 1999). It results from the nonlinear inter-actions between tidal flow and lagoon topography, density gradients, wind stress and the mass input due to freshwater run-offs into the system (AlRamadhan, 1988).

EB lagoon is frequently subject to strong winds which can generate a very complex water circulation. Such a wind effect on the water circulation, including the nearshore bottom currents have been numerically investigated in previous works by Alekseenko et al. (2013a,b), but without considering the effect of salinity.

In the perspective of Z.n. restoration in EB, two main possible abiotic stresses are considered: bottom shear stress and bottom salinity.

Concerning the bottom salinity, there is no clear indication in the literature about the precise lower limit of salinity below which Z.n. would not survive after a long period of low salinity. Charpentier et al. (2005) analyzed the consequences of a sudden

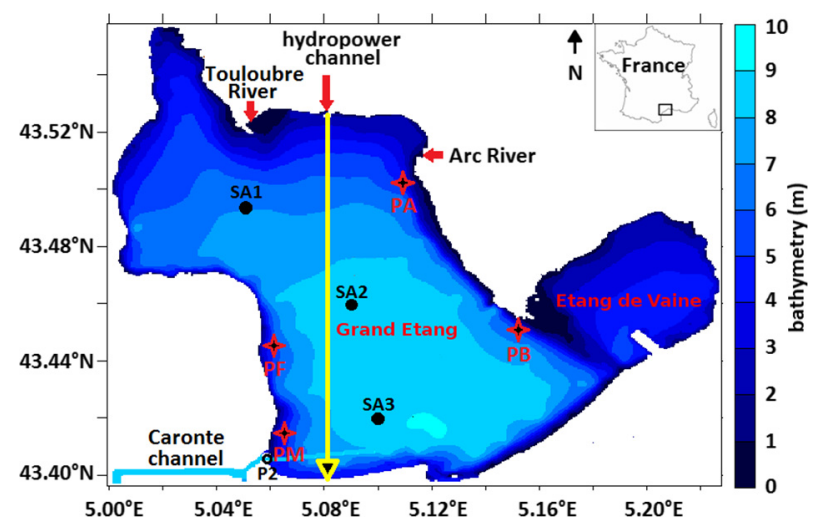

Fig. 1. Etang de Berre and its tributaries (hydropower channel, Touloubre and Arc Rivers), and bathymetry. The arrow is a transect along which some numerical results will be given.

decrease of water salinity on a macrophyte community dominated by Z.n. in another Mediterranean lagoon (Etang de Vaccares; 60 kms from EB) which was accidentally inundated by the freshwater of Rhône River. Z.n. disappeared after three years at low salinity (of about 4-5 PSU). Fernandez-Torquemada and Sanchez-Lizaso (2011) have examined the effect of variation in salinity on growth and survival of Z.n. but for short-term (10 days) laboratory experiments. For each experiment, marked shoots were exposed to different salinity treatments (ranging from 2 to 72 PSU) in aquaria. Their results indicate that Z.n. plants tolerate conditions of hyposalinity. So, the salinity value of 2 PSU was considered as a plausible threshold tolerance of Z.n. in the EB.

Our numerical study was initially undertaken with two aims:

- to emphasize how fast the wind generates a vertical mixing, which is generally expected (e.g., Miller et al., 1990);

- to control a potential risk of a bypass of the freshwater $(S=0)$ of the hydropower plant throughout the replantation areas selected on the eastern shoreline (points PA and PB, in Fig. 1). So, for that study we selected the maximum flow rate of the hydropower plant (i.e., $250 \mathrm{~m}^{3} / \mathrm{s}$ ) and one of the strongest winds (N-NW at 80 $\mathrm{km} / \mathrm{h})$.

In the present numerical study, after validation of our model, two different scenarios are considered, without and with wind stress. In the first scenario (scen.\#1), without wind stress, and starting from an initial homogeneous distribution of salinity ( $S=20$ PSU), we study a stratification process under the influence of a baroclinic pressure gradient due to two dynamical forcings: (a) a seawater influx of high salinity (38 PSU) with a periodic semi-diurnal micro-tide, and (b) a strong freshwater inflow produced by a hydropower plant and two rivers. In the scenario \#2, we analyze the effect of a third forcing mechanism: (c) a strong wind, and we study how rapidly such a wind can destroy the salinity stratification obtained at the end of the scen.\#1. The goals are to determine the temporal evolution of the salinity and the bottom shear stress (BSS) in EB and especially in the nearshore areas. Different values of the roughness parameter relevant for EB nearshore sediments will be considered. The BSS values will be compared with the critical BSS at which the mobility of the corresponding bottom sediments would occur.

\section{Study site}

Among several lagoons located along the Mediterranean shore of France, the Etang de Berre (EB) has been under intense anthropogenic pressure for several decades (Warner, 2012). Salinity has 
varied drastically over the last fifty years, in particular due to the hydroelectric power plant built in 1966, diverting water from the Durance River to an industrial channel. EB is one of the largest Mediterranean brackish lagoons (surface $155 \mathrm{~km}^{2}$; volume

$0.98 \times 10^{9} \mathrm{~m}^{3}$; mean depth $6.5 \mathrm{~m}$ and maximum depth $9.5 \mathrm{~m}$ ). It is composed of two main parts: the Grand Etang and the Etang de Vaine in the Eastern part (Fig. 1). Three main fresh water sources are situated in the Northern part of the lagoon: a hydroelectricity power channel with a maximum runoff capability of $250 \mathrm{~m}^{3} / \mathrm{s}$ during the winter season, and two main rivers (Arc and Touloubre), with runoffs equal to $15 \mathrm{~m}^{3} / \mathrm{s}$ and $10 \mathrm{~m}^{3} / \mathrm{s}$, respectively, corresponding in total to $10 \%$ of the hydropower runoff. In addition, EB is connected to the Mediterranean Sea through a long and narrow channel, called Caronte which permits the entrance of seawater into EB.

In the middle of the 20th century, Z.n. meadows occupied over 6000 ha in EB (Warner, 2012). But subsequently, the lagoon was disturbed by urban and industrial pollution and since 1966 by the hydropower station leading to a very large increase of freshwater inflow and silt. The freshwater inflow was around $3.5 \times 10^{9} \mathrm{~m}^{3}$ per year since 1966 to the end of 1982 , with a maximum of

$6 \times 10^{9} \mathrm{~m}^{3}$ per year in 1976 and 1977 (Ifremer, 1985). So, a drastic reduction of salinity was observed. Kim (1988) reports that before 1966 the EB had a salinity generally larger than 30 PSU; but, after 1966, the salinity has decreased due to the huge runoff, reaching less than 2 PSU in 1978. Concerning the volume of silt, it was around 700000 tons $\left(460000 \mathrm{~m}^{3}\right.$ ) per year since 1966 to 1980 (Ifremer, 1985). Bernard et al. (2007) mentions that the present day near extinction of Zostera in EB probably results from several causes, operating over decades in synergy or successively, namely, pollution (including nutrients), low salinity and turbidity. The inrush of huge amounts of water and silt was obviously the reason for the drastic withdrawal of their lower limit and their eventual near extirpation. The seagrass depth limit, which was 6-9 $\mathrm{m}$ in the early 20th century, decreased to $3 \mathrm{~m}, 1 \mathrm{~m}$ and less than $1 \mathrm{~m}$ by the 1970s, 1992 and 1998, respectively. The total surface area of Zostera meadows in 2004 was only of 1.5 ha.

To alleviate the hydropower disturbance and protect EB against telluric pollution, the annual hydropower runoff was reduced to $1.2 \times 10^{9} \mathrm{~m}^{3}$, since 2005 , and regulated in such a way that $95 \%$ of the salinity measures (weekly average) are larger than 15 PSU and $75 \%$ of these measures are larger than 20 PSU (DRIRE, 2005). In addition, the maximal amount of silt associated to this annual runoff is limited to 60000 tons.

In Fig. 1, we show four control areas (PA, PB, PF, PM) in the Grand Etang which correspond to the places where benthic vegetation existed 50 years ago and then disappeared completely (PF and $\mathrm{PM}$, at the western shore) or partially (PA and PB, at the eastern shore). They also correspond to the main places considered for the replanting program.

After this final hydropower regulation, a replanting program was initiated in these four areas also mentioned by Bernard et al. (2007). This replanting attempt was not successful; this is the main reason for which our numerical studies were focused on understanding the role of two possible abiotic stressors, bottom shear stress and salinity, in the places initially selected for replanting.

Concerning the wind effect on the water circulation in EB lagoon, we used the meteo database provided by SOGREAH (2003), for a ten year period (between 1992-2001), and summarized in Table 2 . The wind in the direction N-NW is largely dominant in intensity and frequency. Note that for an intermediate value of $36 \mathrm{~km} / \mathrm{h}$, the frequency of such a wind is approximately 102 days per year.

It is interesting to mention, for the sake of comparison, that dur-ing the years preceding the hydropower regulation (e.g., in 2002), the periodic seasonal evolution of salinity (mean salinity of the surface layer down to $4 \mathrm{~m}$ depth) reported by Bernard et al. (2007) was ranging from 25 PSU in the summer time to 5 PSU during the winter time.

\section{Model description and validation}

The numerical model concerns the 3D currents due to the three dynamical forcings: sea tide and freshwater runoff (with the consequent baroclinic pressure gradient) and strong wind; it also concerns the 3D salinity and temperature distribution by taking into account the buoyancy forces.

The present study is realized with MARS3D (Model for Applications at Regional Scales). This 3D model is developed by the French Research Institute for the Exploitation of the Sea (Ifremer) for different environmental domains and a variety of applications involving a large range of time-space scales (Lazure and Dumas, 2008; Lazure et al., 2009). MARS3D contains a hydrodynamical model based on the equations proposed by Blumberg and Mellor (1986). It is based on the system of incompressible Reynolds Averaged Navier-Stokes equations in the classical Boussinesq approximation with the hydrostatic assumption. It also takes into account the Coriolis force in the momentum equations.

The surface elevation, $\eta$, is represented by $z=\eta(x, y, t)$, and the bottom relief, $H$, by $z=-H(x, y)$. MARS3D uses a coordinate trans-formation "sigma" to permit a better resolution near the two boundary layers (at the surface and at the bottom). The water col-umn is divided into layers in the transformed vertical "sigma"

coordinate: $\sigma=(z-\eta) /(H+\eta)$; varying from -1 at the bottom to 0 at the free surface.

EB bathymetry obtained from the marine map NAVICARTE 505 of SHOM "Port-Saint-Louis-du-Rhone; Marseille/étang de Berre" using image recognition algorithm have been considered in the present numerical modeling. The numerical aspects of EB configuration and its hydrodynamic simulation were described in Alekseenko et al. (2013a), Alekseenko et al. (2013b) where the effects of refine-ment of the sigma-grid on the computed velocity fields were exam-ined in order to choose an optimal grid for appropriate accuracy and acceptable computational time. In the present study as we do not expect a severe gradient of salinity we use the same grid as before.

\subsection{Boundary conditions}

For the dynamical governing equations, the boundary conditions are the ones used by Alekseenko et al. (2013a). The model involves the horizontal components of the stress at the free surface (wind effect) and the friction at the bottom. For these forcings, in the fresent stmdy, we use the following laws:

$$
\left(\tau_{s, x}, \tau_{s, y}\right)=\rho_{a} C d_{s}\left\|\underline{V}_{10}\right\|\left(U_{10}, V_{10}\right),
$$

where $V_{10}=\left(U_{10}, V_{10}\right)$ is the wind velocity $10 \mathrm{~m}$ above the lagoon surface, $\rho_{a}=1.25 \mathrm{~kg} / \mathrm{m}^{3}$ is the air density, $C d_{s}$ is the surface drag coefficient. For fetch-limited wind-waves at a wind speed of $80 \mathrm{~km} / \mathrm{h}$, we use $C d_{s}=0.0032$ (Young, 1999).

- for the bottom stress components $\left(\tau_{b, x}, \tau_{b, y}\right)$

$$
\left(\tau_{b, x}, \tau_{b, y}\right)=\rho_{0} C d_{b}\|\underline{V}\|(U, V)
$$

with

$$
C d_{b}=\left(\kappa / \ln \left(\frac{z+H+z_{0}}{z_{0}}\right)\right)^{2}
$$


where $\underline{V}$ is the velocity vector with horizontal components $(U, V), C d_{b}$ is the bottom drag coefficient, $\kappa=0.4$ is the Von Karman constant, $\rho_{0}$ is the reference density $\left(\rho_{0}=1015.27 \mathrm{~kg} / \mathrm{m}^{3}\right.$; corresponding to a salinity of $20 \mathrm{PSU}$ and a temperature of $10^{\circ} \mathrm{C}$ ), $z_{0}=0.0035 \mathrm{~m}$ is the bottom roughness (corresponding to gravels).

At the surface $(\sigma=0)$ temperature and salinity equations are:

$\rho_{0} v_{H}\left(\frac{\partial T}{\partial \sigma}, \frac{\partial S}{\partial \sigma}\right)=\left(\frac{Q_{T}}{C_{p}}, 0\right)$,

where $v_{H}$ is the vertical eddy viscosity, $Q_{T}$ - the heat flux at the airsea interface and $C_{p}$ - specific heat of air at constant pressure, $C_{p}=1004 \mathrm{~J} / \mathrm{kg} / \mathrm{K}$.

At the bottom $(\sigma=-1)$ equations for $\mathrm{T}$ and $\mathrm{S}$ are:

$\rho_{0} v_{H}\left(\frac{\partial T}{\partial \sigma}, \frac{\partial S}{\partial \sigma}\right)=(0,0)$.

\subsection{Meshing}

The water column is divided into $N_{\sigma}-4$ internal sigma-layers of constant nondimensional thickness $h_{\sigma}=1 / N_{\sigma}$. A grid refinement is used at the bottom (and at the surface as well), where each layer is halved three times (leading to 4 sublayers of nondimensional thickness; $h_{\sigma} / 2 ; h_{\sigma} / 4, h_{\sigma} / 8$ and $\left.h_{\sigma} / 8\right)$. So, the sigma-grid involves $N_{\sigma}+4$ layers in total. The computations are performed for $N_{\sigma}=20$ (i.e., $h_{\sigma}=1 / 20$ ), for which the thickness of the two extreme layers is reduced to $h_{\sigma}=1 / 160$ (e.g., $5.625 \mathrm{~cm}$ for the deepest place in the EB; i.e., $H=9 \mathrm{~m}$ ).

For the two horizontal directions $(x, y)$ a uniform grid is used with the following number of nodes: $N_{x}=376, N_{y}=355$ (i.e., with a horizontal resolution of $50 \mathrm{~m}$ ).

\subsection{Equation of state}

As described in Lazure and Dumas (2008), in the MARS3D model, the dynamic equations are solved together with transport equations for salinity $(S)$ and temperature $(T)$. These transport equations are coupled with the dynamic equation through buoyancy and are solved in a way consistent with the mass conservation solver in order to be mass preserving, not only for water but also for any tracer.

The density $\rho$ is a mathematical function of temperature, salinity, and pressure. MARS3D includes the 1980 Equation of state, abbreviated EOS80.

\subsection{Model validation setup}

Our numerical model is validated by comparison with vertical profiles of salinity and temperature obtained in EB from three permanent mooring stations (SA1, SA2 and SA3, shown in Fig. 1) equipped with five multiparametric probes, CTD SBE37 (Seabird), placed at five depths. These measurements are reported by Delpy et al. (2012) for a two-year period (May 2008 to May 2010). But unfortunately, the environmental data needed to characterize the three abiotic forcings considered in our model are only partially given by these authors. Finally, the validation was possible for a one-year period (from May 2009 to May 2010) for which all the needed real data sets and real forcings can be found, as it follows. Meteorological forcing was derived from the high-resolution $(3 \mathrm{~km})$ nonhydrostatic mesoscale atmospheric model MM5 (Mesoscale Model 5, Grell et al., 1993, Pairaud et al., 2011, Schaeffer et al., 2011) embedded in the National Center for Envi-ronmental Prediction (NCEP) analysis. For the simulation period we used meteorological forcings, which include non-homogeneous in time and space long wave heat flux, sea level pressure, solar radiation flux, precipitations, humidity, air temper-ature at $2 \mathrm{~m}$ above the EB surface, wind at $10 \mathrm{~m}$ above the EB surface.

Concerning fresh water inputs, (a) daily inputs from the Arc River and Touloubre River have been taken from time series of SIE river discharges (Systéme d'Information sur l'Eau), from the French national database (http://sierm.eaurmc.fr), and (b) weekly mean inputs from the hydropower plant have been obtained from Delpy et al.see their Fig. 2 (2012) by using a graphics treatment tool GetData Graph Digitizer. Concerning the tide height at the entrance of the Caronte channel, the diurnal, semi-diurnal and quart-diurnal harmonic components have been taken into account according to SHOM (Service Hydrographique et Océanographique de la Marine) measurements for Marseilles lagoons.

These experimental results exhibit a periodic seasonal evolution of this almost uniform salinity: around 25 PSU in the summer time and less than 15 PSU in the winter time where the largest hydropower runoffs are used. Weekly mean flows of about $80 \mathrm{~m}^{3} / \mathrm{s}$ are reported in Fig. 2 of Delpy et al. (2012) for January 2009 and 2010. The salinity variation from the surface to the depth of $-6 \mathrm{~m}$ was less than 1 PSU at SA1, SA2 and SA3. So, for the period (20082009), i.e., after hydropower regulation, there was no longer evidence of haline stratification.

\subsection{Model validation results}

The computation has been performed on the high-performance machine of the French Research Institute for Exploitation of the Sea (Ifremer), on 32 nodes. $24 \mathrm{~h}$ of computing time was needed to simulate one month. Thus, approximately 17 days were needed to compute all the period from the January 1, 2009 to the May 31, 2010.

Fig. 2 shows the temporal evolution of the vertical profiles of temperature and salinity from May 1, 2009 to May 31, 2010 at SA1, SA2 and SA3. Our numerical results can be directly compared with the experimental results reported by Delpy et al. (2012) in their Figs. 3 and 4, respectively; for the sake of an easier compar-ison, the color pallet in Fig. 2 was taken as close as possible to the color pallet of Delpy et al. (2012) and the range is the same. A quite good agreement is observed with the measurements. It is seen that for January and February, a period of lowest temperature and largest runoffs (lowest salinity), the temperature is within the range $3-7^{\circ}$ C. Concerning the salinity, from the end of January until the middle of May 2010 it varies within a range 11-15 PSU at all three stations SA1-SA3. In addition, since SA1 is close to the hydro-power inflow and SA3 is close to the Caronte channel (Fig. 1 of Delpy et al., 2012), the subsurface waters at SA1 are fresher than at SA3, while salinity close to the bottom is slightly higher in SA3 than in SA1. These behaviors shown by our model are coherent with the salinity measurements.

\section{Description of two modeling scenarios}

\subsection{Setup}

In the next two sections, two modeling scenarios, much simpler - with constant forcings - are considered (Table 1 ). In the first scenario (scen.\#1), without a wind effect and starting from an initial homogeneous distribution of salinity ( $S=20 \mathrm{PSU}$ ) and the flow at rest, we study a stratification process under the influence of two dynamical forcings: a seawater influx of high salinity (38 PSU) and a strong freshwater inflow produced by the hydropower sta-tion and two rivers. The first aim is to provide a plausible initial 


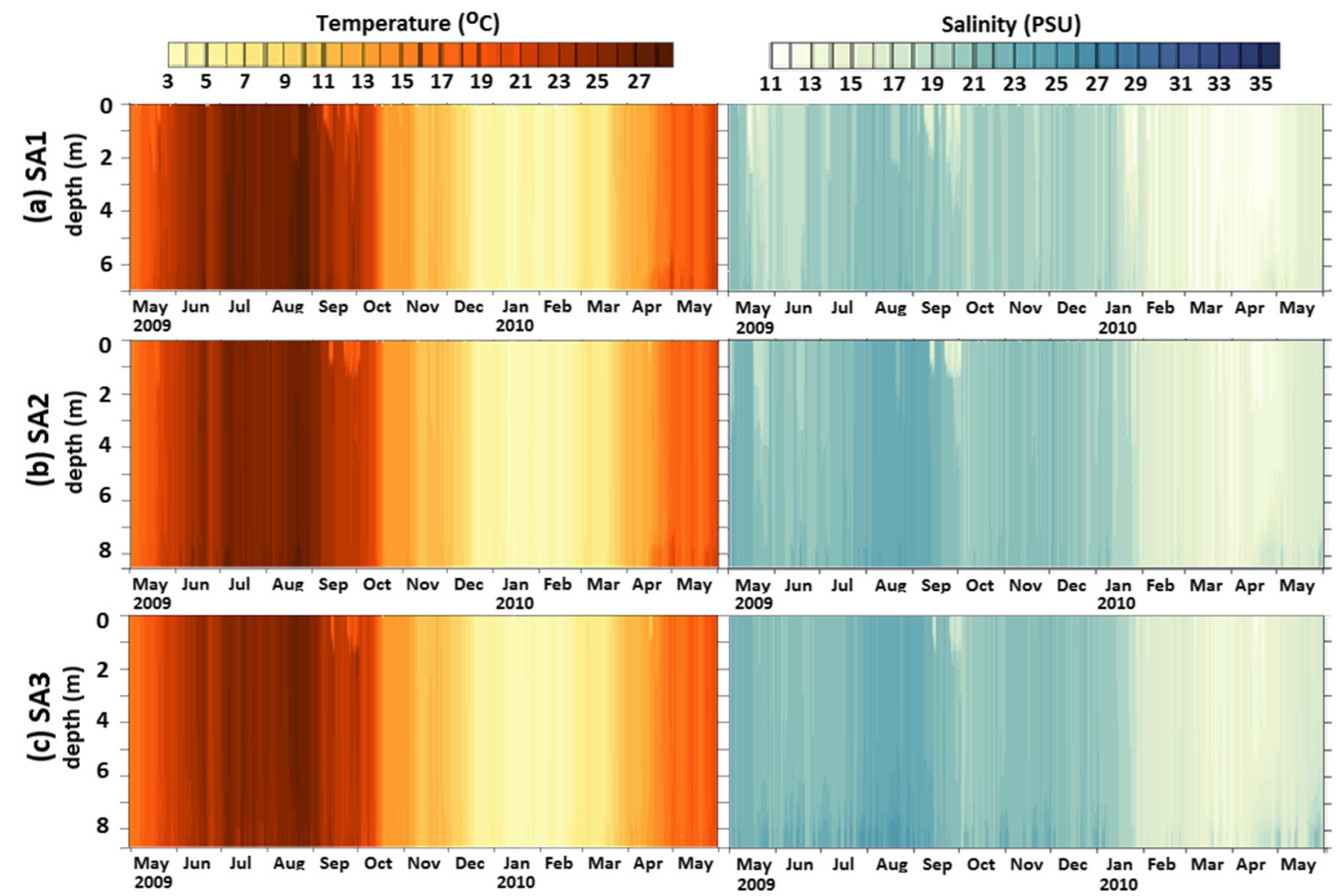

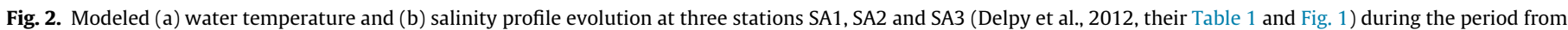
May 1, 2009 to May 31, 2010.
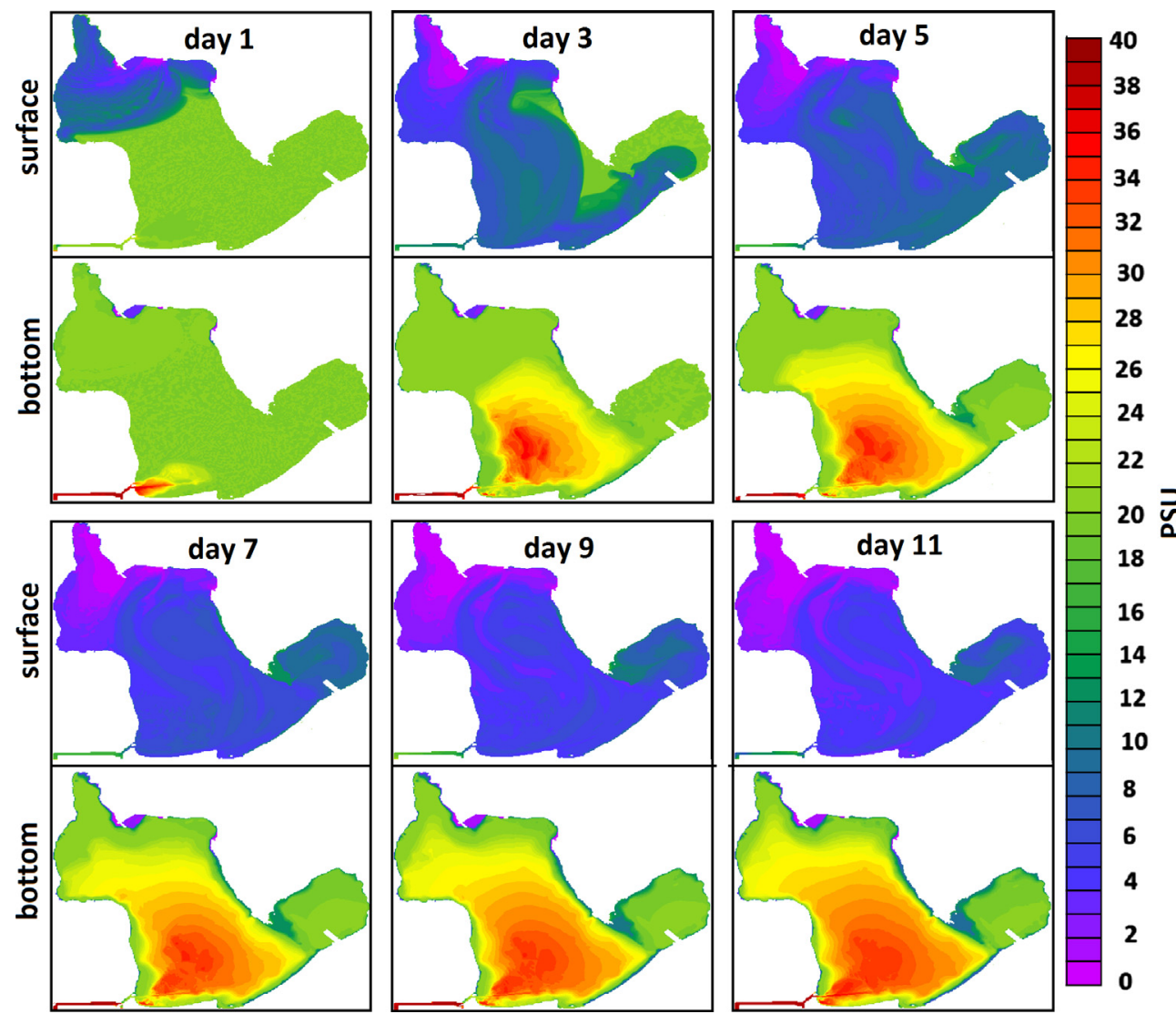

Fig. 3. Salinity evolution (at noon every second day, scen.\#1). At the surface (line 1 for days $1,3,5$; and line 3 for days $7,9,11$ ). And at the bottom (line 2 for days $1,3,5$; and line 4 for days $7,9,11)$. 


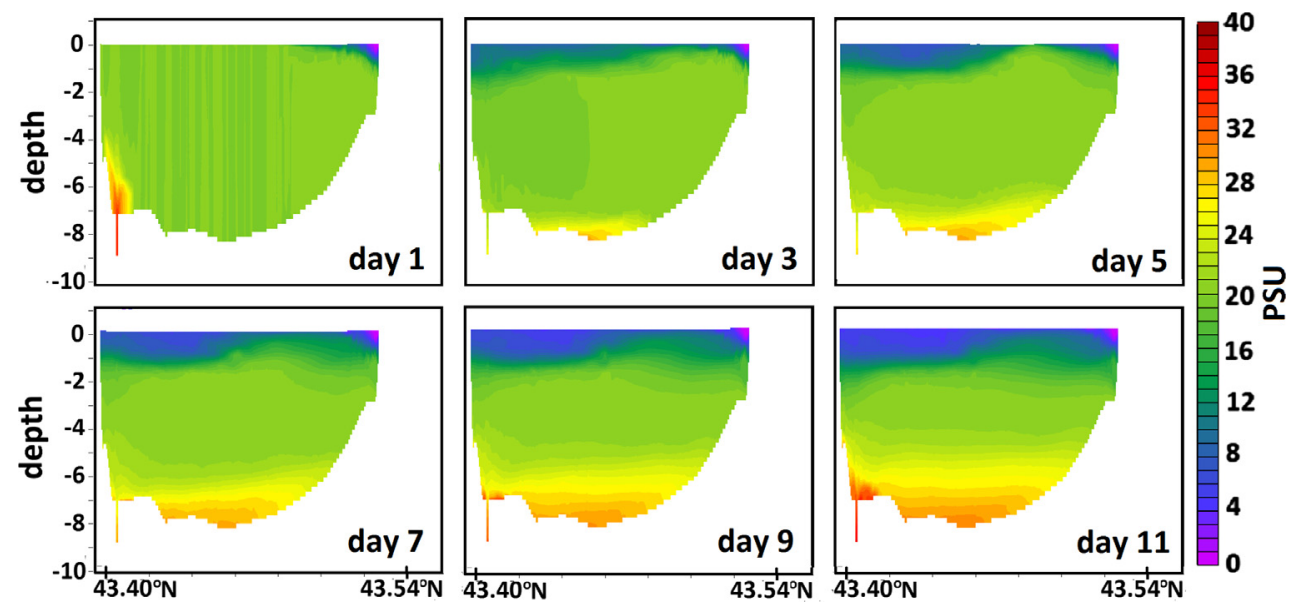

Fig. 4. Salinity evolution - cross sectional profile (at noon every second day, scen.\#1). Line 1 for days $1,3,5$; and line 2 for days 7,9 , 11 .

Table 1

Description of the different scenarios.

\begin{tabular}{|c|c|c|c|c|c|c|c|}
\hline ID & $\begin{array}{l}\text { tidal amplitude (m) } \\
\text { at entrance } \\
\text { of Caronte channel }\end{array}$ & $\begin{array}{l}\text { hydropower } \\
\text { inflow }\left(\mathrm{m}^{3} / \mathrm{s}\right)\end{array}$ & $\begin{array}{l}\text { wind } \\
\text { speed }(\mathrm{km} / \mathrm{h})\end{array}$ & $\begin{array}{l}\text { wind } \\
\text { direction }\end{array}$ & $\begin{array}{l}S(t=0 \mathrm{~s}) \\
(\mathrm{PSU})\end{array}$ & $\begin{array}{l}V(t=0 \mathrm{~s}) \\
(\mathrm{m} / \mathrm{s})\end{array}$ & $\begin{array}{l}\text { simulation time } \\
(\mathrm{d}, \mathrm{h})\end{array}$ \\
\hline Scen.\#1 & 0.3 & 250 & 0 & - & 20 & 0 & $14 \mathrm{~d}$ \\
\hline Scen.\#2 & 0.3 & 250 & $80,60,40,20$ & N-NW & Scen.\#1 & Scen.\#1 & $54 \mathrm{~h}$ \\
\hline
\end{tabular}

salinity stratification to start scen.\#2. Concerning the hydropower runoff, we consider the largest possible value $\left(250 \mathrm{~m}^{3} / \mathrm{s}\right)$ in order to accelerate the process of stratification. The second aim is to imitate the situation existing in the 70s (before the hydropower regulation), where this largest hydropower runoff was used for several weeks (especially in 1976-1977). The simulation time of scen.\#1 was limited to 14 days and for scen.\#2 to $54 \mathrm{~h}$.

For the scenario $\# 2$, in Section 6, initial condition is the solution at the end of scen.\#1. In this Section, we analyze the effect of a third forcing mechanism: a N-NW wind - which is dominant - on the salinity distribution. It is generally expected that the wind will favor mixing. To study this effect we consider mainly a wind of $80 \mathrm{~km} / \mathrm{h}$. The initial aim of our study was to analyze the risk of a bypass of freshswater directly from the hydropower to the western replanting areas (PA and $\mathrm{PB})$. The importance of the mixing effect by the wind is also analyzed in the case of lower speeds: $60 \mathrm{~km} /$ $\mathrm{h}, 40 \mathrm{~km} / \mathrm{h}$ and $20 \mathrm{~km} / \mathrm{h}$.

In addition, to investigate the effect of the bottom current in the replanting areas, we consider the $2 \mathrm{D}$ map of the bottom shear stress (BSS).

The calculations are performed for various bottom roughness values; from $z_{0}=3.5 \mathrm{~mm}$ which represent coarse gravels, to very small $z_{0}$ which correspond to sands and silts, according to the sediment classification given by Berenbrock and Tranmer (2008).

\subsection{Seawater inflow}

The Caronte channel by which the Mediterranean seawater penetrates into the lagoon is narrow (100-250 m wide) and long $(6.5 \mathrm{~km})$. From our previous studies (Alekseeko et al., 2013a, Alekseeko et al., 2013b), we expect that the tidal contribution of the seawater inflow does not create a substantial current in the nearshore replanting zones. So, the sea tide, semi-diurnal, is still simply represented by a harmonic law for the surface elevation at the open boundary of the Caronte channel:

$\eta(t)=0.3 \cos \left(2 \pi\left(t-t_{0}\right) / T\right)$ where $t_{0}$ denotes the initial time of computation, $T$ is the tidal period (about $44714 \mathrm{~s}$ or $12 \mathrm{~h} 25 \mathrm{~min}$ ). The tidal amplitude of $0.3 \mathrm{~m}$ was chosen corresponding to local tide-gauge measurements in the Golf of Fos at the entrance of the Caronte channel. It corresponds to a maximum amplitude (see REFMAR (2015).

The sea salinity at the entrance of the Caronte channel is of 38 PSU, according to the salinity measurements in Caronte channel (at the surface and at the bottom) shown in the Fig. 14 of the report by SOGREAH (2009).

\subsection{Freshwater inflow}

Hydropower runoff is fixed at its maximum, i.e., $250 \mathrm{~m}^{3} / \mathrm{s}$. The two rivers, Arc and Touloubre, are considered with the runoffs of 15 $\mathrm{m}^{3} / \mathrm{s}$ and $10 \mathrm{~m}^{3} / \mathrm{s}$, respectively (which also represents a maxi-mal runoff).

In Sections 5 and 6, for scen.\#1 and scen.\#2, respectively, we will limit the presentation to the most relevant results: (a) salinity distributions at the free surface and at the bottom at different instants, (b) vertical distributions in a selected cross section (shown in Fig. 1), (c) time evolution of salinity in the four near-shore points mentioned in Fig. 1: PF and PM on the western shore, and PA and PB on the eastern shore, (d) time evolution of the salin-ity and velocity profiles at a point P2 in the Caronte Channel and (e) BSS patterns.

\section{Results for hydropower runoff combined with seawater inflow (scen.\#1)}

In this section, we consider the effect of hydropower and river runoffs combined with seawater inflows. At the instant $t=0$, we consider that the EB salinity is homogeneous with a value of 20 PSU, that corresponds approximately to the observations obtained from the mooring sensor at SA2 in January 2009 and 2010 (accord-ing to Fig. 4b in Delpy et al., 2012).

The evolution of the surface and bottom salinity in EB is shown in Fig. 3 for a period of 11 days. After the first $12 \mathrm{~h}$, almost all the 
northern part of the lagoon is refreshed (10-20 PSU); this is the most impacted zone of the lagoon. After 3 days, this zone with low salinity continues to extend to the western region down to the Caronte channel. For almost all the lagoon surface, the salinity decreased from 20 PSU to less than 12 PSU after 4 days, to less than 10 PSU after 7 days, and to less than 6 PSU after 12 days.

Due to the seawater inflow, the bottom salinity in EB is increasing regularly (Fig. 3): the saltier water occupy the deepest parts of the lagoon. After 3 days, the areas impacted by the seawater correspond to EB half part. After 11 days, the bottom salinity exceeds the initial salinity almost everywhere, except in the shallower coastal areas.
Figs. 4 show the salinity distribution in the EB cross section of Fig. 1 (at the same tidal stage as in Figs. 3). The freshwater, being lighter, flows over lagoon waters, whereas the entering seawater, being heavier, flows underneath. It gives rise to a stable haline stratification. The thickness of the fresher subsur-face water increases to $1 \mathrm{~m}$ after 6 days, and to $1.5 \mathrm{~m}$ after 12 days. In the deepest part of the lagoon, the salinity exceeds 26 PSU at the depths 7-9 m after 6 days. After 12 days, low salinity ( $<10$ PSU) is confined to the subsurface layer (with a thickness of $1.5 \mathrm{~m}$ or less). At intermediate depths, i.e., between 2.5-3.5 m, the salinity remains at the initial value of 20 PSU.
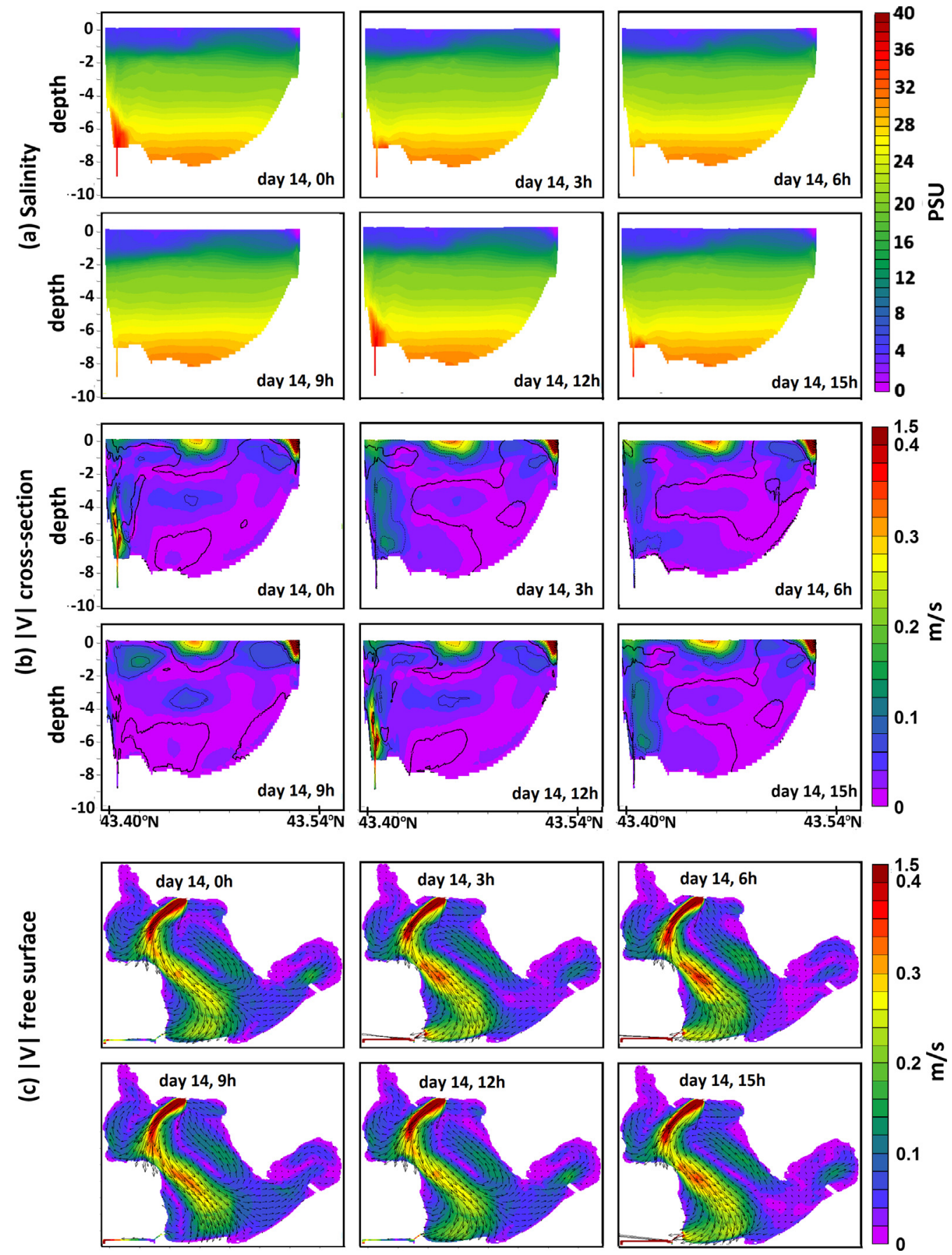

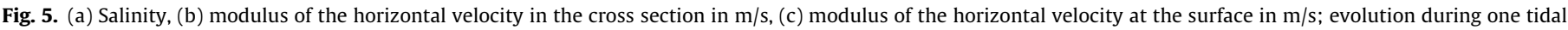
cycle (scen.\#1); day-14, from $t=0 \mathrm{~s}$ to $t=15 \mathrm{~h}$, every $3 \mathrm{~h}$. 
To better understand the cyclic influence of the tide in EB, the evolution of the salinity pattern in the EB cross section is presented in Fig. 5a, every $3 \mathrm{~h}$, during a cycle starting from the day-14 at $t=0$. During a cycle, the pattern of the vertical stratification salinity profile in the water column is not substantially changed, except near the Caronte channel. Similarly the simultaneous evolution of the pattern of the horizontal velocity is shown in Fig. 5b. An intense, non-monotonic, shear flow can be seen near the surface (from $-1 \mathrm{~m}$ to $0 \mathrm{~m}$ ); while the velocity in most part of the cross section is very small, except near the entrance of the Caronte channel. This nonmonotonic behavior in the subsurface can be explained by the complex form of the surface velocity pattern in EB shown in Fig. 5c which demonstrates an intense transverse effect.

The time evolution of salinity is shown in Fig. 6a and b at two depths: $0.4 \mathrm{~m}$ and $0.8 \mathrm{~m}$ which were considered for the replanting program in EB. The salinity level is large enough even for a maximal EDF and rivers runoff, after 12 days without wind. We can conclude that it would not be a stressor for the nearshore replanting program. Nevertheless, since the replanting program is not yet successful, other possible stressors, especially along the eastern shore, would have to be taken into account. In the next section we will consider the wind effect.

In addition, in order to better understand the role of the Caronte channel in the cyclic exchanges between the sea and EB, we present some results (Fig. $7 \mathrm{a}-\mathrm{d}$ ) at a point $\mathrm{P} 2$ situated in the channel at about $50 \mathrm{~m}$ of $\mathrm{EB}$, at which some experiments are reported (SOGREAH, 2009). The cyclic evolution of the vertical profile of the two horizontal components of the velocity is shown in Fig. 7a and b for a period of $25 \mathrm{~h}$ (corresponding approximately to two microtide cycles). The $y$-velocity profiles exhibit a very complex hydrodynamic behavior which is due to the reversing of the current during each cycle. For the times $0,12 \mathrm{~h}$ and $24 \mathrm{~h}$, which corresponds to the flow phase, the salinity in the water column from $-4 \mathrm{~m}$ to the bottom is equal to the sea salinity (Fig. 7c).

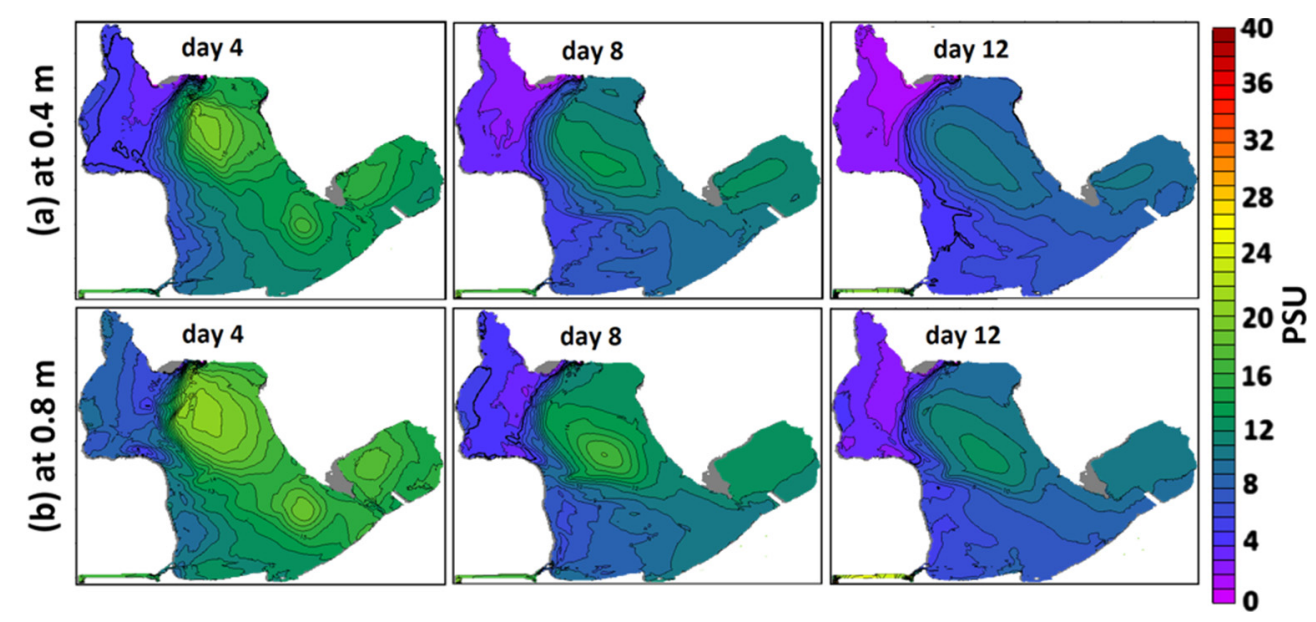

Fig. 6. Time evolution of salinity at different depths: (a) $0.4 \mathrm{~m}$ and (b) $0.8 \mathrm{~m}$, for the days 4,8 and 12 , at noon.
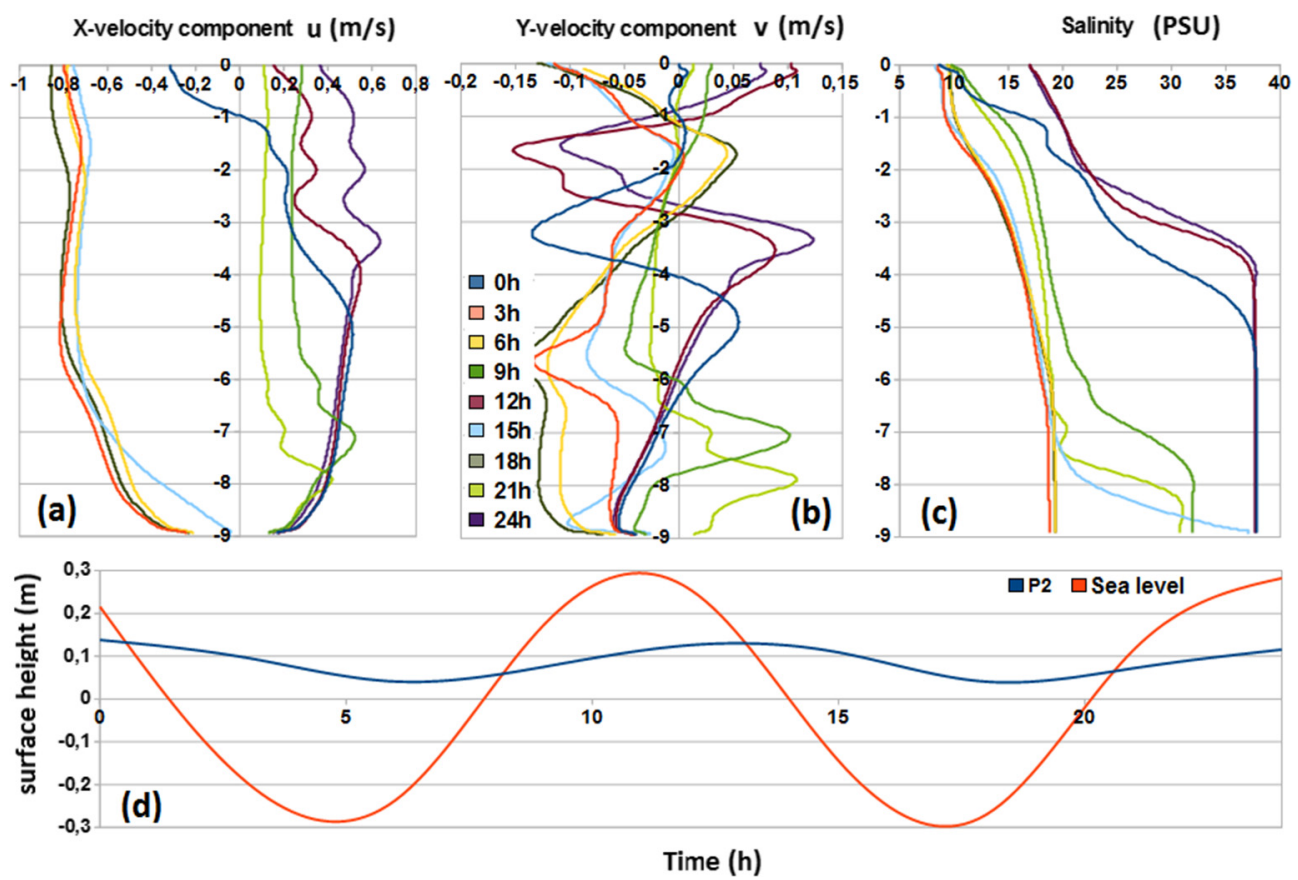

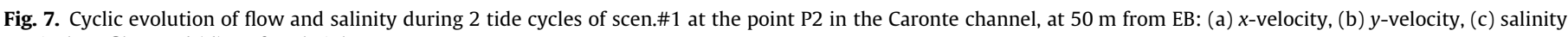
vertical profiles, and (d) surface height. 
The cyclic variation of the surface elevation at P2 is only of $0,1 \mathrm{~m}$, which is 6 times less than the cyclic variation $(0.6 \mathrm{~m})$ of the sea level at the entrance of Caronte channel (Fig. 7d). This important reduction of the tide ranges well corresponds to the observations reported by Ramade (1997).

\section{Results for the salinity distribution and bottom shear stress for a strong wind(scen. $\# 2)$}

EB is a windy area (see Table 2), with a dominant N-NW wind. In a previous work (Alekseenko et al., 2013a), it was shown that strong winds generate strong downwind coastal jets, alongshore, in the shallow water areas of EB. For example N-NW wind produces a coastal jet along the eastern shores (e.g., in PA and PB areas, shown in Fig. 1). Our previous study showed that, due to EB bathymetry, such a coastal jet gives rise to substantial bottom currents, of the order of $0.55 \mathrm{~m} / \mathrm{s}$ in the shallower areas for a $\mathrm{N}$ $\mathrm{NW}$ wind of $80 \mathrm{~km} / \mathrm{h}$. These bottom current can have an impact on the resistance of mud/sand sediments against erosion, which is recognized in the literature to be a limiting factor in SAV recovery.

\subsection{Wind effect on the salinity distribution}

It is known that in lagoons wind effects cause intense vertical mixing (Miller et al., 1990). Now, the goal is to determine if the effect of such a coastal jet on the salinity in PA and PB areas would lead to the mixing effect or not. Could this coastal jet bypass the northern freshwater to PA and PB areas, at least in the case of the highest freshwater inflow of $250 \mathrm{~m}^{3} / \mathrm{s}$ ?

To answer this question, a numerical simulation is first performed for a wind of $80 \mathrm{~km} / \mathrm{h}$. The initial salinity distribution is taken from the last day of scen.\#1, for which a vertical haline stratification was calculated. The numerical results show a very rapid process of destratification. Fig. 8a-c shows the evolution of the vertical distribution of the salinity and the modulus of the horizontal velocity (m/s) every $15 \mathrm{~min}$. At $t=0$ (initial condition corresponding to the end of scen.\#1), the water column is stratified with a low salinity of approximately 6 PSU at a depth of $1.5 \mathrm{~m}$, a higher salinity of 28-34 PSU near the bottom (at a depth of 6-9 $\mathrm{m}$ ) and an intermediate zone of salinity varying between 10 PSU to 24 PSU. After $15 \mathrm{~min}$, the vertical haline stratification is destroyed in the subsurface layer. After $30 \mathrm{~min}$, this mixing affects the zones of low and intermediate salinity; the salinity is quasi homogeneous down to a depth of $4 \mathrm{~m}$, with the mean value of 18 PSU. Then,

\section{Table 2}

Wind speed data base for EB lagoon at Port de Bouc (at the entrance in the EB from the Mediterranean Sea, $43.40735^{\circ} \mathrm{N}, 4.988995^{\circ} \mathrm{E}$ ) after SOGREAH (2003); average over 10years period (1992-2001) of the number of windy days per month with the wind speed observed at $10 \mathrm{~m}$ for three speed levels $(18,36$ and $54 \mathrm{~km} / \mathrm{h})$.

\begin{tabular}{llll}
\hline \multirow{2}{*}{ Month } & \multicolumn{3}{c}{ Number of days with the wind speed } \\
\cline { 2 - 4 } & $>18 \mathrm{~km} / \mathrm{h}$ & $>36 \mathrm{~km} / \mathrm{h}$ & $>54 \mathrm{~km} / \mathrm{h}$ \\
\hline January & 24.3 & 8.3 & 0.7 \\
February & 23.5 & 9.5 & 1.3 \\
March & 28.1 & 11.0 & 1.3 \\
April & 28.5 & 12.5 & 1.8 \\
May & 28.5 & 7.1 & 0.5 \\
June & 27.9 & 7.0 & 0.4 \\
July & 30.0 & 7.1 & 0.3 \\
August & 28.6 & 5.0 & 0.1 \\
September & 26.0 & 7.0 & 0.1 \\
October & 25.1 & 8.4 & 0.3 \\
November & 26.0 & 7.0 & 0.8 \\
December & 25.7 & 12.0 & 1.7 \\
Total per year & 322 & 102 & 9.3 \\
\hline
\end{tabular}

the mixed zone continues to increase, down to $6 \mathrm{~m}$ after $60 \mathrm{~min}$ (Fig. 8a). The salinity was fully homogeneous in the water column after two days (not shown); this behavior is well supported by the salinity measurements reported by Delpy et al. (2012). Already at $t=15 \mathrm{~min}$, there exists a strong current southward in the upper part of the EB (Fig. 8b); it is associated with a tilting of the lagoon surface. At $t=30 \mathrm{~min}$, an opposite current, northward, is seen in the deeper part of EB; the surface tilting is increased (Fig. 8b). This upwelling behavior, with downwind current at the surface and a current of opposite direction at the bottom was already mentioned in Alekseenko et al. (2013a), Alekseenko et al. (2013b). At $t=45 \mathrm{~min}$, the bottom current increases, while the downwind current at the surface is reduced.

After two days, the intense mixing extends to the bottom, with a salinity of about 20 PSU almost everywhere, except in the north-ern and eastern shores where a lower salinity of 8-10 PSU is observed at the surface and at the bottom, near the places of fresh-water inflow (not shown).

In conclusion, Fig. 8a-c show how a strong N-NW wind is able to very rapidly destroy a stable haline stratification which would occur in absence of wind in EB (scen.\#1). This mixing behavior was expected, but only the present numerical simulation allows the prediction of the time needed to destroy the haline stratifica-tion which is known to present the risk of a negative impact on the lagoon biota.

\subsection{Influence of the wind speed on the mixing process}

To understand what wind speed is needed to destroy the haline stratification, the numerical simulation of scen.\#2 was performed for three additional values of the N-NW wind: $60 \mathrm{~km} / \mathrm{h}, 40 \mathrm{~km} / \mathrm{h}$, and $20 \mathrm{~km} / \mathrm{h}$. The salinity evolution at SA2 at three different depths: $2 \mathrm{~m}, 4 \mathrm{~m}$ and $6 \mathrm{~m}$ for the four N-NW wind speeds is shown in Fig. 9. Again, the coincidence of the three salinity curves obtained for these three depths is an indicator of the mixing in at least down to a depth of $6 \mathrm{~m}$. The water column at SA2, reaches a homogeneous salinity of 20-21 PSU after $3 \mathrm{~h}$ for a wind of $80 \mathrm{~km} / \mathrm{h}$, after about $5 \mathrm{~h}$ for a wind of $60 \mathrm{~km} / \mathrm{h}$, and $7 \mathrm{~h} 30 \mathrm{~min}$ for a wind of 40 $\mathrm{km} / \mathrm{h}$. For the N-NW wind of $20 \mathrm{~km} / \mathrm{h}$ there is a tendency toward homogenization, however, even after $24 \mathrm{~h}$ the water col-umn remains stratified. This means that the wind forcing is not strong enough to dominate the two other forcings (seawater and freshwater inflows).

The time of convergence of surface and bottom salinity is shown in Table 3 at the four nearshore control points (replanting areas), and at the three control points in EB (permanent mooring stations).

Considering the very short time needed to harmonize the salinity by the dominant $\mathrm{N}-\mathrm{NW}$ wind and, conversely, the long time needed for the hydropower runoff to create a haline stratification (shown in scen.\#1), we can conclude that EB has a high probability of being well mixed all the year throughout the entire water column. This behavior is consistent with the experimental results seen from Fig. 4 of Delpy et al. (2012).

\subsection{Wind effect on the cyclic exchanges in Caronte channel at the point $P 2$}

As for the scen.\#1, we present some cyclic behaviors (Fig. 10ad) at the point P2 situated in the channel at about $50 \mathrm{~m}$ of EB. The vertical profiles of the two horizontal velocity compo-nents are shown in Fig. 10a and b for a period of $25 \mathrm{~h}$ correspond-ing approximately to two tide cycles. They reveal a hydrodynamic behavior which is less complex than for scen.\#1; this is due to the mixing effect of the wind. 

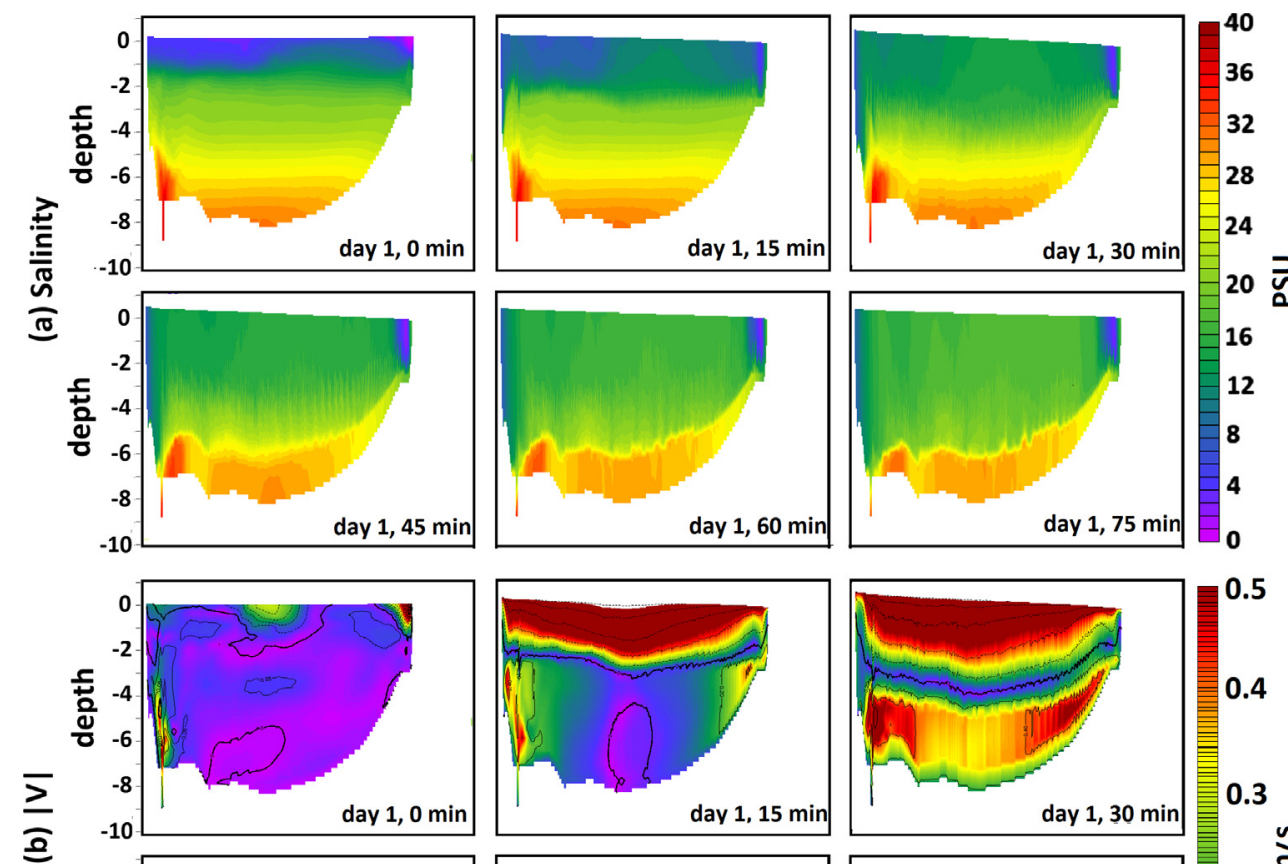

0.4
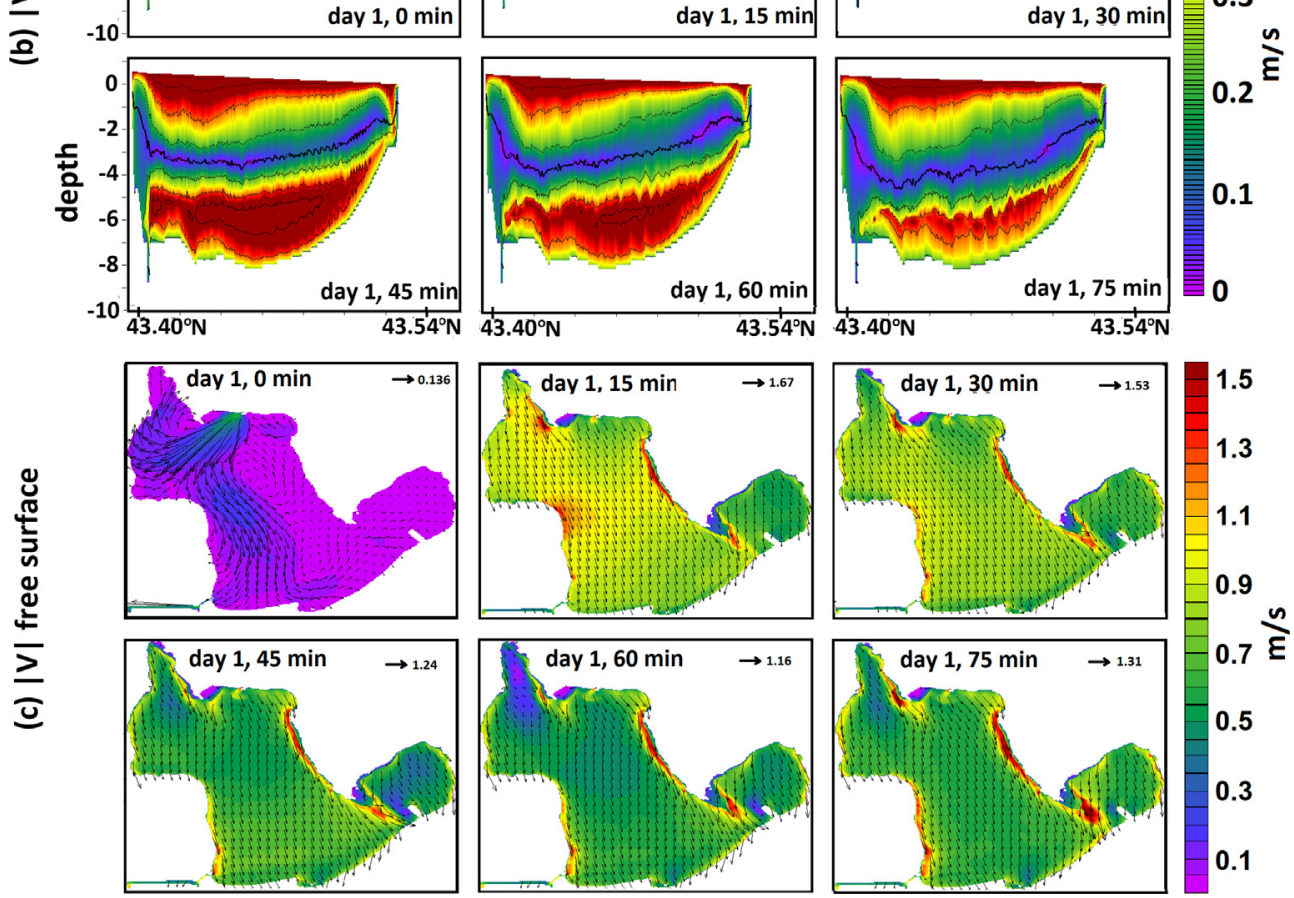

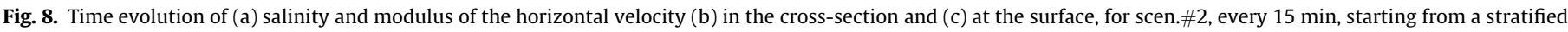
status (end of scen.\#1).

This mixing effect is also responsible of the remarkable homogeneity of the salinity in the water column at any instants except for the times $0 \mathrm{~h}, 12 \mathrm{~h}$ and $24 \mathrm{~h}$, corresponding to flow phases (Fig. 10c). This possibility to find some periods where the salinity is homogeneous in the whole water column in Caronte channel is reported in the Fig. 14 of the report by SOGREAH (2009). During the flow phases the salinity in the water column, from $-5 \mathrm{~m}$ to the bottom, is equal to the sea salinity.

The cyclic variation of the surface elevation at P2 is only of 0,1 $\mathrm{m}$, like for scen.\#1; it is approximately 6 times lower than the tide range at the entrance of Caronte channel (Fig. 10d). This confirms that the tidal wave propagation within the lagoon is lar-gely controlled by the inlet geometry that acts as a filter (DiLorenzo, 1988).
In Fig. 11, we consider the cyclic evolution of the mass flow rate through a transverse $(\mathrm{y}-\mathrm{z})$-cross section in Caronte channel at P2, during two tide cycles. The positive values correspond to the flow phase where the sea water incoming to the lagoon. Fig. 11 shows that for the strong wind, the mass flow rate is mainly outgoing (with a mean value of $-481 \mathrm{~m}^{3} / \mathrm{s}$ ). This ability of the wind effect to counteract the entrance of the sea water was shown from in situ measurements by Ramade (1997). Fig. 11 also shows that for scen.\#1, i.e., for a strong hydropower inflow, the mass flow rate is mainly outgoing (with a mean value of $-211 \mathrm{~m}^{3} / \mathrm{s}$ ).

For the sake of comparison, an additional scenario (called scen. \#0) aimed to identify the effect of the baroclinic pressure gradient alone, without hydropower runoff and without wind, has been considered. In this scen.\#0, this pressure gradient results from 


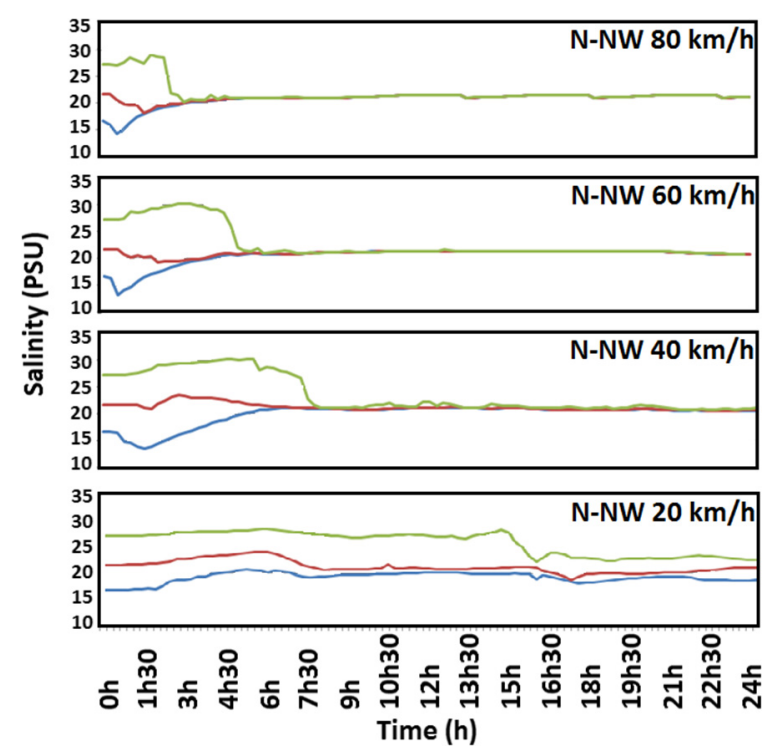

Fig. 9. Salinity evolution at SA2 for scen.\#2, for four N-NW wind speeds of $80 \mathrm{~km} / \mathrm{h}$, $60 \mathrm{~km} / \mathrm{h}, 40 \mathrm{~km} / \mathrm{h}$ and $20 \mathrm{~km} / \mathrm{h}$, at three depths (blue line $-2 \mathrm{~m}$, red line $-4 \mathrm{~m}$, green line $-6 \mathrm{~m}$ ). (For interpretation of the references to colour in this figure legend, the reader is referred to the web version of this article.)

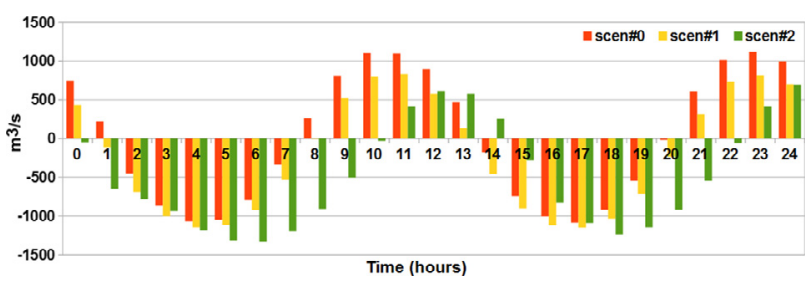

Fig. 11. Cyclic variation of the mass flow rate in Caronte channel for scen.\#2, and comparison with scen.\#1 and an additional scen.\#0.

the difference between the sea salinity of 38 PSU, and an initially uniform salinity of 20 PSU in EB. It leads to an incoming mean value of $+12 \mathrm{~m}^{3} / \mathrm{s}$.

As for the scen.\#1, we present some relevant results (Fig. 10a-d) at the point P2 situated in the channel at about $50 \mathrm{~m}$ of EB. The cyclic evolution of the vertical profile of the two horizon-tal components of the velocity is shown in Fig. 10a and $\mathrm{b}$ for a per-iod of $25 \mathrm{~h}$ (corresponding approximately to two micro-tide cycles). The velocity profiles reveal a hydrodynamic behavior which is less complex than for scen.\#1; this is due to the mixing effect of the wind. This mixing effect is also responsible of the remarkable homogeneity of the salinity in the water column at any instants except for the times $0 \mathrm{~h}, 12 \mathrm{~h}$ and $24 \mathrm{~h}$, corresponding

Table 3

Time of convergence of surface and bottom salinity at the 4 nearshore control points (replanting areas) and in 3 control point in the lagoon; scen.\#2.

\begin{tabular}{|c|c|c|c|c|c|c|c|}
\hline Control points & $\begin{array}{l}\text { PF } \\
\text { Figueroles beach }\end{array}$ & $\begin{array}{l}\text { PM } \\
\text { Martigues }\end{array}$ & $\begin{array}{l}\text { PA } \\
\text { Mouth of Arc River }\end{array}$ & $\begin{array}{l}\text { PB } \\
\text { Pointe de Berre }\end{array}$ & SA1 & SA2 & SA3 \\
\hline (a) Position & $\begin{array}{l}43.4420^{\circ} \mathrm{N} \\
5.0580^{\circ} \mathrm{E}\end{array}$ & $\begin{array}{l}43.4120^{\circ} \mathrm{N} \\
5.0615^{\circ} \mathrm{E}\end{array}$ & $\begin{array}{l}43.5040^{\circ} \mathrm{N} \\
5.1120^{\circ} \mathrm{E}\end{array}$ & $\begin{array}{l}43.4536^{\circ} \mathrm{N} \\
5.1536^{\circ} \mathrm{E}\end{array}$ & $\begin{array}{l}43.495583^{\circ} \mathrm{N} \\
5.049216^{\circ} \mathrm{E}\end{array}$ & $\begin{array}{l}43.459966^{\circ} \mathrm{N} \\
5.09006^{\circ} \mathrm{E}\end{array}$ & $\begin{array}{l}43.421666^{\circ} \mathrm{N} \\
5.10365^{\circ} \mathrm{E}\end{array}$ \\
\hline (b) Depth (m) & 3.2 & 2.4 & 1.6 & 1.6 & 7.2 & 8.6 & 9 \\
\hline (c) Coincidence time (h) & 1 & 1.5 & 0.5 & 1 & 3.5 & 5.5 & 6 \\
\hline (d) Bottom salinity (PSU) & 12.14 & 8.1 & 15.5 & 15.5 & 14.8 & 14.7 & 16.4 \\
\hline
\end{tabular}
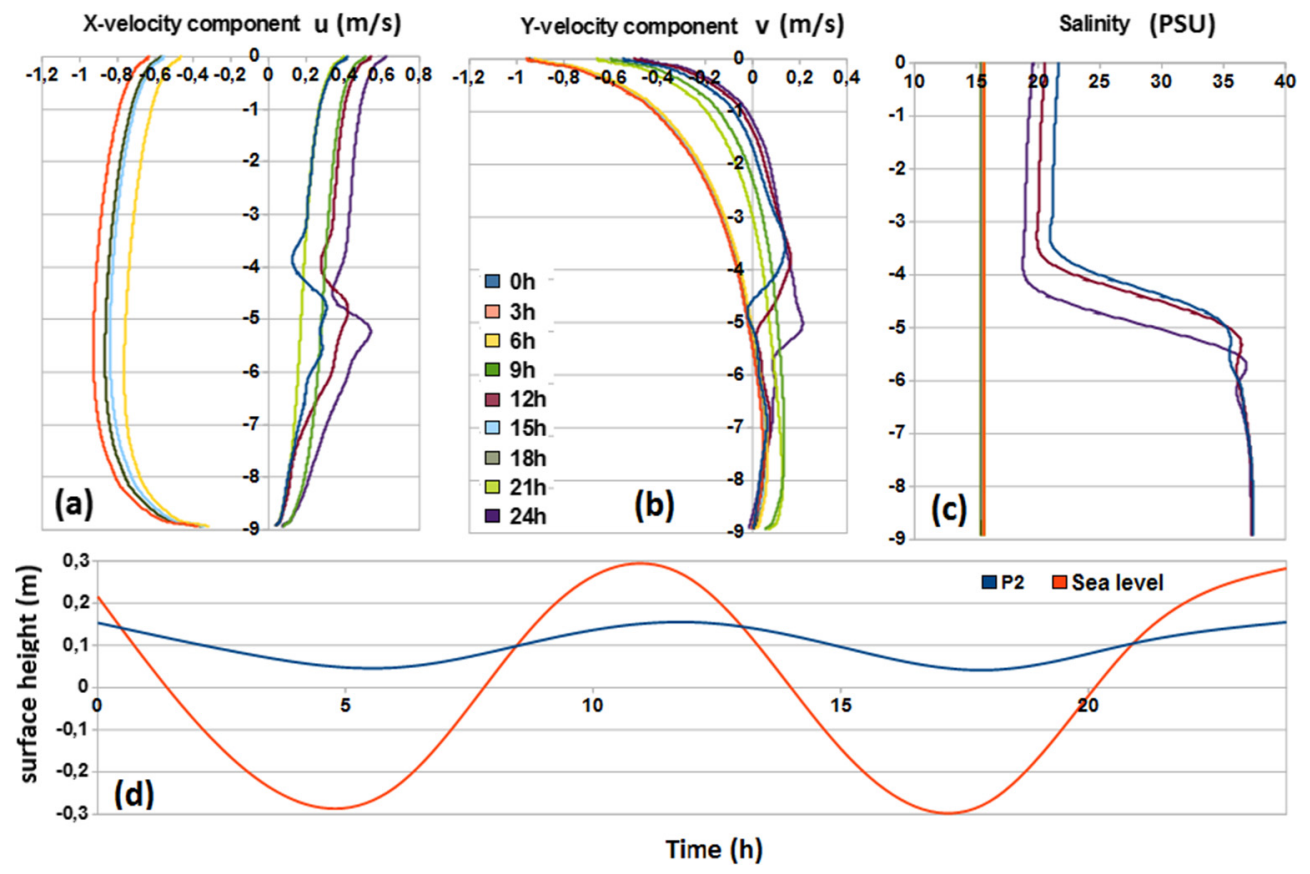

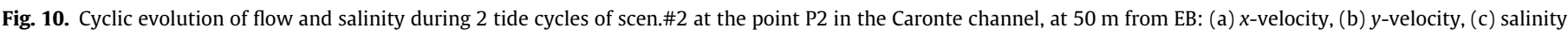
vertical profiles, and (d) surface height. 


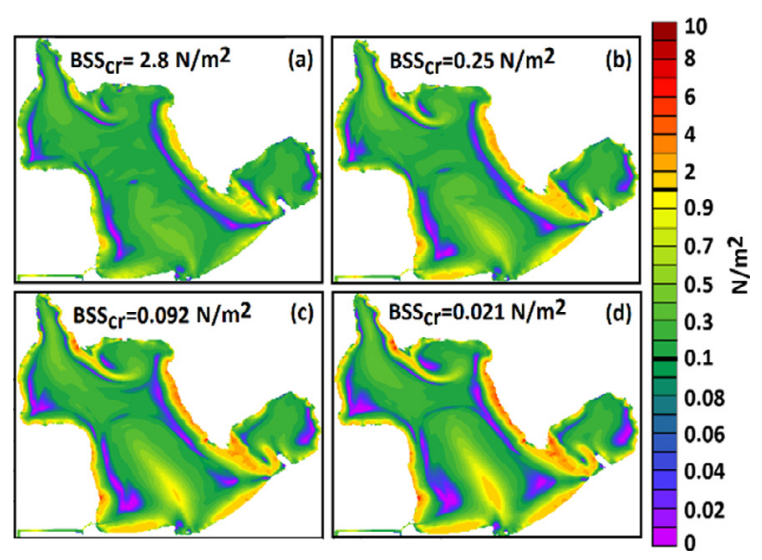

Fig. 12. BSS for a $N-N W$ wind of $80 \mathrm{~km} / \mathrm{h}$, at $12 \mathrm{~h}$; for values of the bottom roughness: (a) $z_{0}=0.35 \mathrm{~mm}$, (b) $z_{0}=0.035 \mathrm{~mm}$, (c) $z_{0}=3.5 \mu \mathrm{m}$, (d) $z_{0}=0.35 \mu \mathrm{m}$; scen.\#2.

to the flow phase (Fig. 10c). For these flow phases the salinity in the water column, from $-5 \mathrm{~m}$ to the bottom, is equal to the sea salinity.

The cyclic variation of the surface elevation at P2 is only of $0,1 \mathrm{~m}$, like for scen.\#1, is approximately 6 times lower than the cyclic variation $(0.6 \mathrm{~m})$ of the sea level at the entrance of Caronte channel (Fig. 10d).

6.4. Wind effect on bottom shear stress (BSS) and comparison with the critical value of BBS for sediment mobility

The BSS patterns are given in Fig. 12. It is particularly interesting to analyze the results in the nearshore areas containing the points PA and PB on the eastern side and the points PM and PF on the western side. They are all subject to the downwind coastal jet created by the N-NW wind. We observe that BSS is larger near the shoreline and decreases along any transect perpendicular to the shoreline. There exists a zone, parallel to the shore line, where BSS presents a minimum (equal to zero). This can be simply explained. It corresponds to the specific characteristic of coastal jet: all along the downwind shorelines, the currents at the surface and at the bottom are downwind, while at a certain distance from the shoreline, the bottom current is opposite (due to the fact that the lagoon is semi-enclosed).

To better understand, at least qualitatively, the impact of such BSS on the sediment mobility in the replanting areas, we can estimate the critical BSS value, BSScr, at which such a mobility would occur. An evaluation of BSScr is proposed by Berenbrock and Tranmer (2008) for a large range of particle diameters $d$ (see their Table 7). Furthermore, according to Dufois and Le Hir (2015), the bottom roughness parameter $z_{0}$ can be connected to the grain-size roughness, $d$, by the following relation: $z_{0}=2.5 \mathrm{~d} / 30$ (see their Appendix 1).

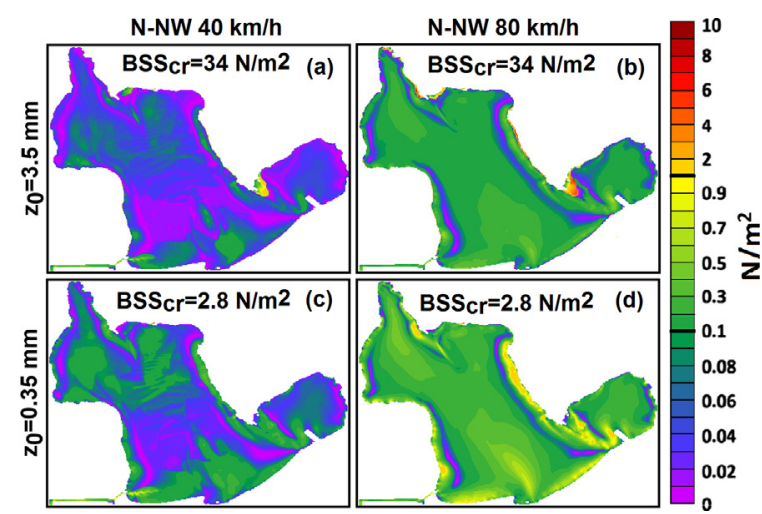

Fig. 13. BSS pattern for two values of N-NW wind speed and two values of the roughness parameter.

Then, the critical values of BSS for sediment mobility, obtained by interpolation for our values of $z_{0}$, are given in the following Table 4 . When the bottom roughness increases, BSS slowly decreases for each of the four control points (Table 4).

In order to follow the recommendations of Cabaço and Santos (2007) and Han et al. (2012) to avoid sediments too soft for restoration, the calculation of the bottom shear stress (BSS) has been performed for $z_{0}=3.5 \mathrm{~mm}$ (coarse gravels). For the sake of comparison, Fig. 13 summarize the BSS results for two values of the bottom roughness parameter $z_{0}$, and two speeds of the $\mathrm{N}$ NW wind.

And if we compare with $\mathrm{BSS}_{c r}$, we see that for the smaller roughness values (ranging from $z_{0}=3.5 \times 10^{-4} \mathrm{~mm}$, to $3.5 \times 10^{-2}$ $\mathrm{mm}$ ) the BSS largely exceeds this critical value (Table 4). Finally, we have determined the BSS values for a N-NW wind speed of $40 \mathrm{~km} / \mathrm{h}$ (which is blowing for around 100 days per year). The results, also given in Table 4, confirm that BSS largely exceeds BSS $_{c r}$

- at least for the silt sediments (ranging from $z_{0}=3.5 \times 10^{-4} \mathrm{~mm}$, to $3.5 \times 10^{-3} \mathrm{~mm}$ ). This confirms the possibility that the coastal jet could generate sediment mobility which could have a negative impact for SAV replanting.

\section{Discussion and conclusion}

This work is focused on the numerical simulation of mechanisms of haline stratification and destratification in a semienclosed Mediterranean lagoon (Etang de Berre), and their influence throughout the lagoon, in particular in the nearshore areas selected for a replanting program of submerged aquatic vegetation (Zostera noltei). The goal was mainly to evaluate the intensity of two potential abiotic stressors on the SAV replanting: bottom shear stress and salinity.

Our first model scenario (scen.\#1)- without wind forcing, but involving baroclinic pressure gradient forces, confirm that these

Table 4

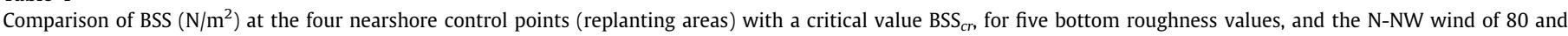
40 km/h; scen.\#2.

\begin{tabular}{|c|c|c|c|c|c|c|c|c|c|c|}
\hline \multirow[t]{2}{*}{$z_{0}(\mathrm{~mm})$} & \multirow[t]{2}{*}{ Sediment } & \multicolumn{2}{|c|}{$\mathrm{PF}$} & \multicolumn{2}{|c|}{ PM } & \multicolumn{2}{|c|}{ PA } & \multicolumn{2}{|c|}{$\mathrm{PB}$} & \multirow[t]{2}{*}{$\mathrm{BSS}_{\mathrm{cr}}$} \\
\hline & & $80 \mathrm{~km} / \mathrm{h}$ & $40 \mathrm{~km} / \mathrm{h}$ & $80 \mathrm{~km} / \mathrm{h}$ & $40 \mathrm{~km} / \mathrm{h}$ & $80 \mathrm{~km} / \mathrm{h}$ & $40 \mathrm{~km} / \mathrm{h}$ & $80 \mathrm{~km} / \mathrm{h}$ & $40 \mathrm{~km} / \mathrm{h}$ & \\
\hline $3.5 \times 10^{-4}$ & Fine silt & 1.34 & 0.25 & 1.53 & 0.36 & 3.63 & 0.87 & 1.84 & 0.43 & 0.021 \\
\hline $3.5 \times 10^{-3}$ & Coarse silt & 1.25 & 0.17 & 1.16 & 0.22 & 2.87 & 0.56 & 1.27 & 0.29 & 0.092 \\
\hline $3.5 \times 10^{-2}$ & Medium sand & 1.02 & 0.1 & 0.76 & 0.12 & 1.66 & 0.25 & 0.71 & 0.16 & 0.25 \\
\hline $3.5 \times 10^{-1}$ & Fine gravel & 0.67 & 0.04 & 0.32 & 0.05 & 0.45 & 0.1 & 0.26 & 0.06 & 2.8 \\
\hline 3.5 & Coarse gravel & 0.21 & 0.04 & 0.23 & 0.04 & 0.43 & 0.1 & 0.15 & 0.4 & 34 \\
\hline
\end{tabular}


forces bring heavier seawater to the lagoon bottom, while freshwater inflow, lighter, coming from a hydropower plant and two tributaries overflows the lagoon waters. The calculations, which are performed for a period of 14 days, show that the process of haline stratification - which was expected - is very slow, even for the highest hydropower runoff of $250 \mathrm{~m}^{3} / \mathrm{s}$. An extrapolation of the computed salinity values show that in the case of a longer duration (typically one month or more) the salinity would reach almost zero in the entire nearshore water column. It partly confirms the explanation given by Warner (2012) for the massive seagrass destruction in EB; the hydropower inflow reached $6 \times 10^{9} \mathrm{~m}^{3}$ per year in 1976 and 1977; i.e., about 6.5 times the total volume of EB. Indeed, with such a flow rate of $250 \mathrm{~m}^{3} / \mathrm{s}$, several months are needed to deliver such a large volume of freshwater.

In scen.\#2, we have found, conversely, how rapidly a N-NW wind of $80 \mathrm{~km} / \mathrm{h}$ can produce a strong current and destroy the vertical haline stratification, forming a homogeneous salinity distribution in almost the entire water column. It confirms that the mixing is so rapid that any bypass of freshwater from hydropower plant to the eastern shoreline is not possible. In the four nearshore replanting areas, the mixing is produced in a very short time (between half an hour to one hour and half, depending on the depth and on the distance to the hydropower station) and tends to maintain a bottom salinity at a level larger than 12 PSU. Thus, with the present hydropower regulation in EB, the salinity in not a stressor for SAV replanting. This is consistent with the recent observations of resilience of Z.n. meadows made by divers of a non-profit association (called L'Etang Nouveau) in several areas very close to the shoreline. These observations are very promising as the divers confirm that the observed meadows are increasing year after year (Basile, 2015 and Basile, 2016).

The other possible abiotic stressor, the bottom shear stress (BSS), has been carefully investigated. BSS maps have been obtained for the entire EB lagoon. It was particularly interesting to analyze the results in the nearshore areas containing the points $\mathrm{PA}$ and PB on the eastern side and the points PM and PF on the western side. They are all subject to the downwind coastal jet created by the N-NW wind.

When the bottom roughness decreases (from gravels to silts), BSS slowly increases for each of the four control points; while BSS decreases. And the comparison with $\mathrm{BSS}_{c r}$, show that for the smaller roughness values, the BSS largely exceeds this critical value. This behavior is confirmed for a N-NW wind of lower speed $(40 \mathrm{~km} / \mathrm{h})$ which is blowing very frequently (around 100 days per year). BSS still largely overpass $\mathrm{BSS}_{c r}$ - at least for the silt sedi-ments. This confirms the possibility that the coastal jet could gen-erate sediment mobility leading to a negative impact for SAV replanting.

Our BSS results can be used as a guide for the selection of future nearshore replanting sites. Most of the places initially selected in EB for the replanting program appeared to be not productive. The present study could be useful to select more relevant nearshore areas for a possible extension of the replanting program, after an appropriate characterization of bottom sediments.

More generally, the present study will be useful to alert the persons in charge of replanting programs in other sites in the world (lagoons, estuaries, lakes) subject to strong winds and coastal jets, to take into account the large variation of BSS in the nearshore areas subject to coastal jets.

In any case, we plan to extend as soon as possible the present modeling of the effects of strong winds in the nearshore replanting or resilience areas. The modeling of BSS could be improved by taking into account the wave dynamics (including breaking waves). We plan also to use MARS3D to study the sediment transport (including erosion).

\section{Acknowledgements}

We acknowledge financial supports by the French Water Agency (Agence de l'Eau-RMC - convention N 2010-0042) and by the Regional Council (Conseil Regional Provence-Alpes-Cote d'Azur): Projet HYDROSYS - Subvention N 2008-11944CA and the French Ministry of Foreign Affairs (ARCUS-Russia program). We also acknowledge $\mathrm{PhD}$ grants received from the French Ministry of Higher Education and Research (Direction des Relations Europeennes et Internationales et de la Cooperation: reseau formation-recherche Franco-Russe). Part of this research is also a contribution to the grant of Russian Foundation for Basic Research (RFBR) N16-35-00526, to the Labex OT-Med (No. ANR-11LABX-0061) funded by the French Government "Investissements d'Avenir" program of the French National Research Agency (ANR) through the $A *$ MIDEX project (no ANR-11-IDEX-0001-02). This study was carried out also as a part of MERMEX/MISTRALS and is a contribution to the international SOLAS, IMBER and LOICZ projects. We would like to thank our colleagues Christian Kharif, Richard Kotarba and also Alexander Sukhinov for the advises and discussions devoted to this work. We specially thank Pascal Bazile, diver of the non-profit Association l'Etang Nouveau, for his remarkable observation of zostera resilience in many places in EB.

\section{References}

Alagna, A., Vega Fernández, T., D’Anna, G., Magliola, C., Mazzola, S., Badalamenti, F., 2015. Assessing Posidonia oceanica seedling substrate preference: an experimental determination of seedling anchorage success in rocky vs. sandy substrates. PLoS One 10 (4), e0125321.

Alekseenko, E., Roux, B., Sukhinov, A., Kotarba, R., Fougere, D., 2013a. Coastal hydrodynamics in a windy lagoon. Comput. Fluids 77, 24-35.

Alekseenko, E., Roux, B., Sukhinov, a., Kotarba, R., Fougere, D., 2013b. Nonlinear hydrodynamics in a mediterranean lagoon. Nonlinear Process. Geophys. 20 (2), 189-198. http://dx.doi.org/10.5194/npg-20-189-2013.

Al-Ramadhan, B.M., 1988. Residual fluxes of water in an estuarine lagoon. Estuar. Coast. Shelf Sci. 26, 319-330.

Bazile, P., 2015. Le rapide développement des herbiers de zostéres de l'étang de Berre. 27 mai 2015. <https://letangnouveau.wordpress.com/2015/05/27/lerapide-developpement-des-herbiers-de-zosteres-de-letang-de-berre/>. Bazile, P.,

2016. Exposition de l'Étang Nouveau sur les zostéres - Istres 18 au 27 oct. 2016. <https://letangnouveau.wordpress.com/2016/10/11/expositionde-letang-nouveau-sur-les-zosteres-istres-18-au-27-octobre-2016/>.

Berenbrock, C., Tranmer, A.W., 2008. Simulation of Flow, Sediment Transport, and Sediment Mobility of the Lower Coeur d'Alene River, Idaho. U.S. Environmental

Protection Agency; Scientific Investigations Report 2008-5093.

Bernard, G., Boudouresque, C.F., Picon, P., 2007. Long term changes in Zostera meadows in the Berre lagoon (Provence, Mediterranean Sea). Estuar. Coast. Shelf Sci. 73, 617-629.

Blumberg, A.F., Mellor, G.L., 1986. A description of a Three-Dimensional Coastal Ocean Circulation Model, Geophysical Fluid Dynamics Program. Princeton Univ., Princeton, New Jersey, pp. 1-16.

Cabaço, S., Santos, R., 2007. Effects of burial and erosion on the seagrass Zostera noltii. J. Exp. Mar. Biol. Ecol. 340, 204-212.

Charpentier, A., Grillas, P., Lescuyer, F., Coulet, E., Auby, I., 2005. Spatio-temporal dynamics of a Zostera noltii dominated community over a period of fluctuating salinity in a shallow lagoon, Southern France. Estuar. Coast. Shelf Sci. 64, 307315.

Delpy, F., Pagano, M., Blanchot, J., Carlotti, F., Thibault-Botha, D., 2012. Man-induced hydrological changes, metazooplankton communities and invasive species in the Berre Lagoon (Mediterranean Sea, France). Marine Pollut. Bull. 64 (9), 19211932. http://dx.doi.org/10.1016/j.marpolbul.2012.06.020.

DiLorenzo, J.L., 1988. The overtide and filtering response of small inlet/bay systems. In: Aubrey, D.G., Weishar, L. (Eds.), Lecture Notes and Coastal and Estuarine Studies. Springer-V, New-York, USA, pp. 24-53.

DRIRE, 2005. Dossier d'avenant a la concession Electricité de France de Salon SaintChamas sur la Durance. Rapport pour les membres de la commission départamentale des sites perspectives et paysages des Bouches du Rhône de 16 Décembre 2005.

Duarte, C.M., Sintes, T., Marba, N., 2013. Assessing the CO2 capture potential of seagrass restoration projects. J. Appl. Ecol. 50, 1341-1349.

Dufois, F., Le Hir, P., 2015. Formulating fine to medium sand erosion for suspended sediment transport models. J. Mar. Sci. Eng. 3, 906-934. http://dx.doi.org/ $10.3390 /$ jmse3030906.

Fernandez-Torquemada, Y., Sanchez-Lizaso, J.L., 2011. Responses of two Mediterranean seagrasses to experimental changes in salinity. Hydrobiologia 669 (1), 21-44. 
Grell, G.A., Dudhia, J., Stauffer, D.R., 1993. A description of the fifthgeneration Penn State / NCAR mesoscale model (MM5). NCAR Technical Note, NCAR/ TN-398 +STR, pp. 117

Han, Q., Bouma, T.J., Brun, F.G., Suykerbuyk, W., van Katwijk, M.M., 2012. Resil. Zostera noltii Burial or Erosion Disturb. 449, 133-143. http://dx.doi.org/ 10.3354/meps09532.

HCMR (Hellenic Centre for Marine Research)/EEA (European Environment Agency), 2009. Distribution of the marine Angiosperm Posidonia oceanica and Zostera sp. in the Mediterranean. <http://www.eea.europa.eu/data-and-maps/figures/ distribution-of-the-marine-angiosperm-posidonia-oceanica-and-zostera-sp-inthe-mediterranean/\#parent-fieldname-title>.

Ifremer, 1985. Apports liquides et solides du Canal EDF de Saint Chamas, juillet 1985.

Kim, K.T., 1988. La salinité et la densité des eaux étangs de Berre et de Vaine (Méditerranée nord-occidentale) relations avec les affluents et le milieu marin voisin. Marine Nat. 1 (1), 37-58.

Lazure, P., Dumas, F., 2008. An external-internal mode coupling for a 3D hydrodynamical model for applications at regional scale (MARS). Adv.Wat. Res. 31, 233-250.

Lazure, P., Garnier, V., Dumas, F., Herry, Ch, Chifflet, M., 2009. Development of a hydrodynamic model of the Bay of Biscay. Validation of hydrology. Continen. Shelf Res. 29 (8), 985-997.

Lirman, D., Serafy, J.E., 2008. Documenting Everglades restoration impacts on Biscayne Bay's shallowest benthic habitats. First Annual Report. CERP Monitoring and Assessment Plan Component: Activity Number 3.2.3.3. Miami, FL.

The Mermex group: Durrieu de Madron, X., Guieu, C., Sempéré, R., Conan, P., Cossa, D., D’Ortenzio, F., Estournel, C., Gazeau, F., Rabouille, C., Stemmann, L., Bonnet, S., Diaz, F., Koubbi, P., Radakovitch, O., Babin, M., Baklouti, M., BanconMontigny, C., Belviso, S., Bensoussan, N., Bonsang, B., Bouloubassi, I., Brunet, C., Cadiou, J.-F., Carlotti, F., Chami, M., Charmasson, S., Charriére, B., Dachs, J., Doxaran, D., Dutay, J.-C., Elbaz-Poulichet, F., Eléaume, M., Eyrolles, F., Fernandez, C., Fowler, S., Francour, P., Gaertner, J.C., Galzin, R., Gasparini, S., Ghiglione, J.-F. Gonzalez, J.-L., Goyet, C., Guidi, L., Guizien, K., Heimbürger, L.-E., Jacquet, S.H.M., Jeffrey, W.H., Joux, F., Le Hir, P., Leblanc, K., Lefévre, D., Lejeusne, C., Lemé, R., Loÿe-Pilot, M.-D., Mallet, M., Méjanelle, L., Mélin, F., Mellon, C., Mérigot, B. Merle, P.-L., Migon, C., Miller, W.L., Mortier, L., Mostajir, B., Mousseau, L., Moutin, T., Para, J., Pérez, T., Petrenko, A., Poggiale, J.-C., Prieur, L., Pujo-Pay, M.,
Pulido-Villena, Raimbault, P., Rees, A.P., Ridame, C., Rontani, J.-F., Ruiz Pino, D. Sicre, M.A., Taillandier, V., Tamburini, C., Tanaka, T., Taupier-Letage, I., Tedetti, M., Testor, P., Thébault, H., Thouvenin, B., Touratier, F., Tronczynski, J., Ulses, C. Van Wambeke, F., Vantrepotte, V., Vaz, S., Verney, R., 2011. Marine ecosystems responses to climatic and anthropogenic forcings in the Mediterranean. Prog. Oceanogr. 91 (2), 97-166. doi:10.1016/j.pocean.2011.02.003.

Miller, J.M., Pietrafesa, L.J., Smith, N.P., 1990. Principles of hydraulic management of coastal lagoons for aquaculture and fisheries, FAO Fisheries Technical Paper 314

Millot, C., 1999. Circulation in the Western Mediterranean Sea. J. Mar. Syst. 20, 423 442.

Pairaud, I.L., Gatti, J., Bensoussan, N., Verney, R., Garreau, P., 2011. Hydrology and circulation in a coastal area off Marseille: validation of a nested 3D model with observations. J. Mar. Syst. 88, 20-33.

Pickerell, C., 2007. Eelgrass (Zostera marina) Restoration in Jamaica Bay: Initial Site

Selection and Potential for Success; Cornell Cooperative Extension; oct.18. <http://www.nyc.gov/html/dep/pdf/jamaica_bay/jbaysymp-Chris_Pickerell_ Eelgrass.pdf>.

Ramade, A., 1997. Ouverture du tunnel du Rove: incidence sur les échanges hydraulique; rapport Ramade-GERIM (août 1997).

REFMAR, 2015. <http://refmar.shom.fr/en/fos-sur-mer>.

Schaeffer, A., Molcard, A., Forget, P., Fraunie, P., Garreau, P., 2011. Generation mechanisms for mesoscale eddies in the Gulf of Lions: radar observation and modeling. Ocean Dyn. 61 (10), 1587-1609.

Smith, N.P., 1994. Water, salt and heat balance of coastal lagoons. In: Kjerfve, B. (Ed.), Coastal Lagoon Processes. Elsevier, Amsterdam, pp. 69-101.

SOGREAH, 2003. Berre-Etudes de premiere phase, Evaluation comparative des impacts maritimes des solutions B et T, rapport MAR/PSI- 2360023; 28 April 2003

SOGREAH, 2009. Modélisation hydrodynamique de l'Etang de Berre et des milieux annexes. Rapport N1740286, Fev. 2009.

Telesca, L. et al., 2015. Seagrass meadows (Posidonia oceanica) distribution and trajectories of change. Sci. Rep. 5, 12505. http://dx.doi.org/10.1038/srep12505.

Warner, R.F., 2012. Environmental impacts of hydroelectric power and other anthropogenic developments on the hydro morphology and ecology of the durance channel and the Etang de Berre, southeast France. J. Environ. Manage. $104,35-50$.

Young, I.R., 1999. Wind Generated Ocean Waves. Elsevier, pp. 288. 